Fall 11-28-2021

\title{
Leadership Rounding to Improve Patient Satisfaction in Pediatric Ambulatory Care
}

Tara J. Haskell

University of St. Augustine for Health Sciences, t.haskell@usa.edu

DOI: https://doi.org/10.46409/sr.JDBR1371

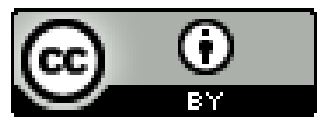

This work is licensed under a Creative Commons Attribution 4.0 License.

Follow this and additional works at: https://soar.usa.edu/scholprojects

Part of the Nursing Administration Commons, Pediatric Nursing Commons, and the Quality Improvement Commons

\section{Recommended Citation}

Haskell, T. J. (2021). Leadership Rounding to Improve Patient Satisfaction in Pediatric Ambulatory Care. [Doctoral project, University of St Augustine for Health Sciences]. SOAR @ USA: Student Scholarly Projects Collection. https://doi.org/10.46409/sr.JDBR1371

This Scholarly Project is brought to you for free and open access by the Student Research at SOAR @ USA. It has been accepted for inclusion in Student Scholarly Projects by an authorized administrator of SOAR @ USA. For more information, please contact soar@usa.edu, erobinson@usa.edu. 
Leadership Rounding to Improve Patient Satisfaction in Pediatric Ambulatory Care

\author{
Tara Haskell, MS, RN, CPN
}

School of Nursing, University of St Augustine for Health Sciences This

Manuscript Partially Fulfills the Requirements for the

Doctor of Nursing Practice Program and is Approved by:

Mary Brann, DNP, RN

Cathy Kleiner Ph.D., RN

Approved: November 28, 2021 


\begin{abstract}
Practice Problem: Low patient satisfaction has been linked to poor treatment compliance, patients leaving the practice, staff decreased job satisfaction, and high staff turnover (Haskard Zolnierek \& DiMatteo, 2009; Prakash, 2010). Magnet reporting has identified wide discrepancies in ambulatory clinics, with some clinics reporting below benchmark patient satisfaction ratings. PICOT: In pediatric ambulatory and primary care services, how will the implementation of leader-led customer service rounding, compared to current practice, increase family and/or patient satisfaction over 4 weeks?
\end{abstract}

Evidence: Key findings are that the rounding needs to be population-specific, intentional, and swiftly followed up when problems are identified. The body of evidence suggests that implementing leadership rounding in a setting such as pediatric ambulatory care could benefit the patients served by building trust and communication.

Intervention: Implementation of a leadership rounding survey modified from current hospital rounding tools on patients and families by nursing leaders.

Outcome: While post-data results did not have a statistically significant change from the predata results, several identified needs for the clinics were discovered. Clinical significance, in this project, addresses the family-identified needs for change, which will impact future care.

Conclusion: Rounding on families in pediatric ambulatory care is an integral part of the care that can identify patient satisfaction needs and practice differences between clinics, leading to more consistency in patient satisfaction in the future. 


\section{Leadership Rounding to Improve Patient Satisfaction in Ambulatory Care}

Pediatric medicine focuses on the family and creates a nurturing, healing environment for children in all care settings. However, families do not always have a positive pediatric experience. Healthcare organizations aim to continuously improve the quality of care and the patient's perceptions of care. The Institute of Healthcare Improvement (IHI) developed the Quadruple Aim that supports improvement in the patient experience, which consists of improving quality care and patient satisfaction, reducing costs, and enhancing the work-life balance of healthcare workers (IHI, 2020). These aims have been a driving force for organizations in improving their satisfaction scores. Additionally, multiple insurance agencies are starting to require patient satisfaction measurements as part of their reimbursement for care provided, pay-for-performance incentives, and specialists' board certifications (Agency for Healthcare Research and Quality [AHRQ], 2017).

The clear challenge to deliver high-quality care and meet patients' expectations is seen in all areas of medicine. An interprofessional team often cares for patients in ambulatory clinics, including nurses, medical assistants, technicians, and providers. From the time the family walks in the door until they go home, each interprofessional team member plays a part in the patient experience. The way the team interacts with each other and the patient impacts the family's satisfaction with care. Press Ganey (2017) identified three important factors in patient satisfaction, which are teamwork, careful listening by the providers, and the nurses remaining attentive to the patient's needs. Taking measures to improve patient satisfaction scores impacts quality clinical care and organizational success (AHRQ, 2017). 


\section{Significance of the Practice Problem}

The perceptions of the patient and family are often reflected in patient satisfaction surveys. For example, if patients perceive their provider did not spend enough time with them, they may indicate poor satisfaction even if they were diagnosed and treated accurately. Additionally, communication with the care team that is perceived as poor can lead to confusion about treatment, and the patient can lose trust in the team and care provided (Davis et al., 2017).

Dissatisfied patients are more likely to change physicians and be non-compliant with their treatment plan (Haskard Zolnierek \& DiMatteo, 2009; Prakash, 2010). A Vitals (2018) survey stated that $20 \%$ of patients changed physicians due to long wait times, and $30 \%$ of patients walked out of an appointment due to long waits. The survey also correlated wait time to a physician's average rating (Vitals, 2018). Changing healthcare providers can often lead to inconsistency in care, but by having a consistent provider with effective communication skills, illness prevention, and improved self-care management can increase (AHRQ, 2020).

Poor patient satisfaction can have a significant impact on the healthcare system. Research findings have linked low patient satisfaction to decreased job satisfaction and high staff turnover (Haskard Zolnierek \& DiMatteo, 2009; Prakash, 2010). It is estimated that a medical practice could lose up to $\$ 200,000$ annually due to the loss of a patient over dissatisfaction (Prakash, 2010). Another financial impact on medical practices is malpractice lawsuits (Levinson, 1997). It is shown that primary care physicians with high satisfaction scores and lower rates of malpractice lawsuits often spend more time with their clients (Levinson, 1997). As a result of the correlation between high patient satisfaction and lower malpractice lawsuits, the American Board of Medical Specialists certification is working to include patient satisfaction scores into their process; 
additionally, several healthcare insurance agencies and healthcare plans incorporate patient experience ratings into incentives for providers (AHRQ, 2020).

Many countries around the world require patient satisfaction surveys. The World Health Organization's efforts to move the quality of care forward worldwide helped create the Framework for Person-Centeredness (Larson et al., 2019). This framework includes patient experiences as an essential part of quality care. Improving patient satisfaction is considered a necessary component of universal health coverage and meeting the Sustainable Development Goals (SDGs) worldwide (Larson et al., 2019). Countries are already using a variety of measures to look at patient experiences or patient satisfaction. In Germany, this data is used for benchmarking patient satisfaction and is made available to the public (Bitzer et al., 2012). Gamble (2012) completed a global patient satisfaction survey that showed the United States with a $77 \%$ satisfaction rating overall compared to a global rating of $66 \%$, while Germany was at $72 \%$. Out of the seven main countries surveyed, the United States had the highest rating (Gamble, 2012).

Several tools are used in the United States to measure patient satisfaction. The hospital in this DNP project used the NRC Health survey tool to track patient behaviors, preferences, wants, and needs (NRC Health, n.d.). The hospital reports the main patient-family experience rating publicly; for internal tracking purposes, each clinic and specialty area has separate reporting of patient satisfaction scores. The NRC survey tool has four nursing-sensitive measures that are reported to the Magnet designation cycles. This status is critical for this hospital as they have had Magnet status since 2005 (Children's Hospital Colorado [CHCO], 2015). Magnet status identifies hospitals that have reached the "gold standard" in care delivery, patient experience, and use of evidence-based care processes and procedures (American Nurses Credentialing Center [ANCC], 
n.d.). Maintaining high patient satisfaction scores in the ambulatory departments is challenging.

Due to the nature of the specialty department, they each function differently and provide different services. These differences between departments can lead to patient and family satisfaction variances; for example, one department did not meet the patient satisfaction benchmark for the four nursing questions in all eight quarters reported, but others met the benchmark in all eight quarters.

\section{PICOT Question}

The following population, intervention, comparison, outcome, and time (PICOT) question is used to guide this project. In $(\mathrm{P})$ pediatric ambulatory and primary care services, how will the (I) implementation of leader-led customer service rounding, (C) compared to current practice, $(\mathrm{O})$ increase family and/or patient satisfaction $(\mathrm{T})$ over 4 weeks?

\section{Evidence-Based Practice Framework and Change Theory}

This project used the Johns Hopkins Nursing Evidence-Based Practice Model (JHNEBP) framework (Dang \& Dearholt, 2018). The framework can be applied in many nursing settings, from the bedside to leadership and academia (Melnyk \& Fineout-Overholt, 2019). Along with the JHNEBP framework, Kotter's eight-stage change process theory for leading change, guided project planning, and sustainability efforts (Kotter, 2012).

\section{Johns Hopkins Nursing Evidence-Based Practice Model}

The JHNEBP model is a step-by-step process that is linear and guides evidence-based practice (EBP) implementation. The model has a process and tools available to help nurses implement EBP changes in healthcare settings (Melnyk \& Fineout-Overholt, 2019). The framework has three essential components that reflect using EBP in healthcare settings: inquiry, practice, and learning (Dang \& Dearholt, 2018).

The first step in the 19 linear steps is identifying the practice question (Dang \& Dearholt, 
2018). Once the practice question was determined, an inquiry into the evidence was made, and the project leader completed the evidence grading. The evidence includes internal and external factors that might influence the project's implementation, such as change culture, resources, and current standards (Melnyk \& Fineout-Overholt, 2019). Once all the evidence was compiled, a recommendation for change was made. The last phase in the JHNEBP is translation, which analyses the evidence to determine how feasible the project would be (Dang \& Dearholt, 2018). Once the project was determined to be viable by the organization's leadership, an action plan was created to implement the change and evaluate the outcome. The final step in the JHNEBP is disseminating the findings to the organization's leadership and other professional organizations or journals.

\section{Kotter's Eight-Stage Change Process}

Kotter's change model provides clear steps to follow, with an underlying concept that people need to be given a reason to feel like the change should happen (Melnyk \& FineoutOverholt, 2019). The eight stages start with creating a climate for change, then progressing to enabling the organization, and finally sustaining change (Kotter, 2012). The driver for this project is that patient satisfaction should always be a consideration despite challenges. Having team members passionate about this change was an essential piece to help build urgency and encourage others to want successful change (Melnyk \& Fineout-Overholt, 2019). Creating a climate for change was made through the first three stages of creating the sense of urgency, forming a coalition, and creating the vision (Kotter, 2012). Not only do people need to be invested in the idea, but also straightforward and easy-to-understand communication is vital for effective change (Kotter, 2012). Communicating this vision of change was met by sharing patient stories of both positive and negative experiences. The investment from the unit manager was 
essential, by examining barriers; additionally, the Patient Family Experience representatives helped build the momentum and empowered the staff to change (stage five) (Kotter, 2012). Knowing how each stakeholder felt about the change before implementation, made the discussions of barriers such as training, time, and compliance, as well as, the importance of patient satisfaction improvement, be productive and guide the empowerment of the teams to sustain the new practice of rounding (Barrow et al., 2021).

Stage six of Kotter's change process is creating quick wins (Kotter, 2012). Smalls wins included gaining facility approval and setting a date for "go live." These small wins gave momentum and a sense of accomplishment for moving forward. Celebrating these small wins helped move the project into stage seven, which built on the change (Kotter, 2012). The last stage of Kotter's Change Theory is making it stick (Kotter, 2012). Sustainability is essential in any project to make a lasting impact; immediate success can fade to complacency. The transition of ownership was passed on to the directors for the ambulatory departments, who are passionate about improving patient satisfaction and building a culture to sustain the change to other clinics. Unfortunately, the sustainability phase has hit some barriers due to the staffing shortage related to COVID-19. Once the staffing shortage has improved and there are fewer barriers to rounding, the sustainability process will improve.

\section{Evidence Search Strategy}

Following the JHNEBP model, the literature has been reviewed to critique and appraise the evidence-based practices regarding leadership rounding. The literature review was conducted using the search engines ProQuest, CINAHL Complete, PubMed, Nursing OVID, EBSCO, and Google Scholar. Inclusion criteria included the years 2006 to present and the English language. The search included the following keywords: leadership rounding, rounding, executive rounding, 
intentional rounding, nurse leader rounds, patient rounding, purposeful rounding, patient satisfaction, patient experience, family experience, pediatric, NRC, ambulatory, and outpatient. Leadership rounding was also included in the literature findings, often with hourly rounding research or protocols. Articles with only hourly rounding were excluded, but only after screening for leadership rounding. Exclusionary terms used included nurse-physician rounding, bedside rounding, interprofessional rounding, pharmacy, disease-specific focus, pain, infection control, and staffing. Phrases were searched using Boolean operators "and," "not," and "or." The purpose of this review was to support a proposed Doctor of Nursing Practice (DNP) project intervention of doing leadership rounding in ambulatory pediatric areas.

\section{Evidence Search Results}

The searches produced more than 3,845 articles. A total of 115 were screened for inclusion and exclusion criteria, which excluded 77 articles initially. There were 38 articles that met the inclusion criteria. A full-text review was completed from these articles, and 12 articles were selected for their substantial contribution to this project and are included in the evidence table (see Appendix A). Articles excluded from the evidence table were lower evidence articles, including white papers, quality improvement projects, student evidence-based practice projects, and literature reviews, which are found in the Prisma Chart (see Figure 1).

The overall strength of the recommendations was determined using the JHNEBP model. Studies supporting the implementation of leadership rounding ranged from level I to $\mathrm{V}$. This rating is dependent on the study design, with quantitative studies being level I and level V are a quality improvement or literature review (Dang \& Dearholt, 2018). The recommendation is that only "A" and "B" level studies support EBP. The 12 most relevant studies were evaluated and appraised using the JHNEBP model (see Appendix A and B). This criterion means the articles 
are categorized based on having consistent or reasonably consistent results, sufficient sample sizes, or comprehensive literature reviews, description of the specific technique, and transparency (Dang \& Dearholt, 2018). This recommended criterion was used to evaluate the literature returned from the literature search. The studies in the evidence table that supported the implementation of leadership rounding ranged from level I to III with A or B ratings. This body of evidence is mainly in the acute care settings; however, there is enough evidence to suggest the potential benefit of leadership rounding in ambulatory care settings as well.

\section{Themes with Practice Recommendations}

Hourly rounding is a foundational concept from which leadership rounding was established in many institutions. Much of the literature addresses leadership rounding being used in conjunction with hourly or bedside rounding. The literature review for this project looked at articles on rounding and specifically leadership rounding and its impact on patient satisfaction. Several themes come up in the literature: rounding, intentional rounding, quality of care, or leadership rounding on patient satisfaction.

\section{Rounding}

Best practice on inpatient units has found that rounding on patients either hourly or every other hour has several positive benefits (East et al., 2020; Meade et al., 2006; Ogbolu et al., 2016; Rea et al., 2018; Rondinelli et al., 2012). Regularly interacting with a nurse or staff member such as a certified nursing aide leads to trusting relationships and can reduce anxiety in patients and families (Ogbolu et al., 2016; Rea et al., 2018). A study of 11 southern California hospitals determined that the act of rounding improved patient satisfaction scores (Rondinelli et al., 2012). A key component identified for successful rounding was that the rounding results need to be reviewed, and structures around results need to be reevaluated for better outcomes 
(Rondinelli et al., 2012). Additionally, managers identified the need for flexibility with rounding timing and routine as staff and unit needs change for continued sustainability (Rondinelli et al., 2012).

In a systematic review of 28 articles looking at family-centered rounding, patient satisfaction was impacted positively, with families reporting having an increased understanding of information and confidence in the medical team (Rea et al., 2018). A study with 145 patients showed statistically significant improvement in patients' perception of care and satisfaction with care, as measured with the tools Perception of Quality Nursing Care Scale and the Patients' Satisfaction with Nursing Care Quality Questionnaire (Shin \& Park, 2018). In a qualitative study in 11 California hospitals, the two main themes identified were hourly rounding, improved patient perception of being well cared for, and overall patient satisfaction. An extensive nationwide study with 27 nursing units was foundational for rounding, and patient satisfaction was statistically improved for hourly and two-hour rounding (Meade et al., 2006). However, the limitations in this study included the lack of raw data determined by each hospital's different survey vendors (Meade et al., 2006).

\section{Intentional Rounding}

The literature suggests using intentional rounding is beneficial for patient satisfaction (Ayaad et al., 2019; Cody \& Williams-Reed, 2018; East et al., 2020; Harrington et al., 2013; Kirk \& Kane, 2016; Ogbolu et al., 2016; Rondinelli et al., 2012; Shin \& Park, 2018). Intentional rounding is scripted, structured, and timely, and the literature shows that both nurses and patients respond positively to intentional rounding (East et al., 2020; Ogbolu et al., 2016). One userfriendly way identified for doing intentional rounding was using a digital tablet with rounding software and pre-scripted questions, leading to consistency in the delivery of patient rounding questions (Cody \& Williams-Reed, 2018). Using a tablet for tracking and consistency 
helped to balance out some of the negatives identified in the literature, such as extra workload, not enough time, lack of staff engagement, and variability in settings such as the emergency department

(ED) (Harrington et al., 2013; Kirk \& Kane, 2016).

\section{Quality of Care}

Despite some negatives, it is documented in the literature that rounding increases the quality of care, as supported in 9 of the 12 supporting articles for this project (Ayaad et al., 2019; Cody \& Williams-Reed, 2018; East et al., 2020; Harrington et al., 2013; Kirk \& Kane, 2016; Meade et al., 2006; Ogbolu et al., 2016; Rondinelli et al., 2012; Shin \& Park, 2018). Some of the main benefits identified with rounding are reducing falls and using call lights (Harrington et al., 2013; Kirk \& Kane, 2016; Meade et al., 2006; Rondinelli et al., 2012; Shin \& Park, 2018). Another positive aspect is improving the nurse-patient relationship, as it is reinforced by regular rounding and improves patient quality care (East et al., 2020; Shin \& Park, 2018). Leadership rounding impacts quality, builds patient-nurse communication, trust, and monitors other quality aspects, such as hourly rounding (Cody \& Williams-Reed, 2018; East et al., 2020). Another significant quality factor is cultural competency. Often, patients express complaints after leaving, making it hard to meet their cultural expectations (Ogbolu et al., 2016). Completing leadership rounds can help identify themes and needs to develop culturally competent care for diverse patient populations (Ogbolu et al., 2016).

\section{Leadership Rounding and Patient Satisfaction}

Leadership rounding builds on the benefits of hourly rounding and supports the patient's needs further. Three studies specific to leader rounding demonstrated increased patient satisfaction related to nursing concern and being well cared for (Ayaad et al., 2019; Rondinelli et 
al., 2012; Tan \& Lang, 2015). Another benefit found in the research, was that leadership rounding can assess patient needs and trends in care to impact future care (Ogbolu et al., 2016; Rondinelli et al., 2012). A small systematic review with only three articles had weak evidence but still demonstrated improved patient satisfaction (Tan \& Lang, 2015). A retrospective descriptive study done by Cody \& Williams-Reed (2018) showed one negative score for "nurses listened carefully" and one positive score for "nurses explained things in a way you could understand," this study did not demonstrate a statistically significant improvement in the overall mean of hospital patient satisfaction scores. However, the study had limitations, as it did not report what percentage of patients were rounded on, though the stated expectation was $90 \%$ of patients, and there were management changes in the middle of the research, who did not receive the same training (Cody \& Williams-Reed, 2018).

\section{Gap in the Literature and Recommendations}

There is an abundance of information that rounding on adult patients and inpatient departments impacts improving patient satisfaction. However, there is limited literature on pediatric ambulatory care rounding. Although not specific to leadership rounding, one article in the search did demonstrate that rounding on pediatric patients and families has a significant impact on perceptions of care, leading to better patient satisfaction (Rea et al., 2018). There is also limited literature specific to the ambulatory setting; however, the evidence synthesized demonstrates that leadership rounding can impact patient satisfaction and is more related to nurse-sensitive care (Ayaad et al., 2019; Cody \& Williams-Reed, 2018; Rondinelli et al., 2012; Tan \& Lang, 2015). Key findings are that the rounding needs to be population-specific, intentional, and swiftly followed up on when problems are identified (Ayaad et al., 2019; Cody \& Williams-Reed, 2018; East et al., 2020; Harrington et al., 2013; Kirk \& Kane, 2016; Meade et 
al., 2006; Ogbolu et al., 2016; Rondinelli et al., 2012; Shin \& Park, 2018). The body of evidence suggests that implementing leadership rounding in a setting such as pediatric ambulatory care could benefit the patients served by building trust and quality of care.

\section{Setting, Stakeholders, and Systems Change}

Implementation of this project was in the ambulatory department in a large southwestern children's hospital, which serves a multi-state region for specialty care. The leadership team at this hospital is committed to high-quality, coordinated care using reimagined and realized care to improve child health. The hospital strives to build community trust and stand by its values in all services provided. Two units were pilots for the initial implementation of the leadership rounding tool and evaluation of outcomes. Both the Child Health Care (CHC) and the Digestive Health Institute (DHI) clinics serve pediatric patients from infancy to adolescence and have large volumes of visits monthly. CHC focuses on primary care, and DHI focuses on esophageal, intestinal liver, pancreatic, and nutritional specialties. A convenience sample of patients and their caregivers, who were willing to participate in the survey, was rounded on during the intervention period, with a goal of 20 or more patient families rounded per month per clinic. Rounding was planned to be performed by unit managers, associate clinical managers (ACM's), and the project leader; however, due to changes made necessary by the impact of COVID-19, only the project leader completed the rounds.

A gap analysis, and a Strengths, Weaknesses, Opportunities, and Threats (SWOT) analysis, were conducted to determine the department's needs. Ambulatory department directors were contacted regarding the unit's needs; this included both directors for Primary Care, Community Programs, and Ambulatory Specialty Care. It was identified that leadership rounding was being completed hospital-wide but was lacking in ambulatory care settings. Another need 
identified was that there was considerable variability for some department scores for the nursesensitive questions on the internally shared NRC survey, as reported to the Magnet redesignation committee. The plan for this project was to address these needs.

Other key stakeholders were included in the approval process, such as the vice president (VP) and medical providers of network of care (NOC), VP for Ambulatory Services, Child Health Clinic Clinical Manager and Associate Clinical Manager, Digestive Health Clinical Manager and Associate Clinical Manager, Ambulatory Care Patient Family Experience Chair, Rounds Plus (Rounds+) representative, and Family Advisory Council Chair. Other stakeholders for this project are patients, families, other clinic staff, physicians, dietitians, and nurse practitioners. Both ambulatory care directors approved and supported the project.

The sustainability plan included sharing the results with the ambulatory care leadership team and expanding leadership rounding to all clinics. Leadership rounding is expected to be incorporated with handwashing rounding to decrease barriers with time. The leadership rounding has been placed on hold because of extreme staffing shortages due to the global pandemic of COVID-19's impact on healthcare during 2020/2021. However, both directors for ambulatory care have stated they would like to implement rounds again as soon as staffing hits an adequate number. Different ambulatory departments are looking at other healthcare staff completing the rounding to assist the nurse leaders, such as orthopedic technicians in the orthopedic clinics. Interprofessional collaboration was needed during the implementation and will also be needed to support the sustainability of leadership rounding. The whole team needs to support patient rounding. Quality care begins at the initial interaction, through intentional scripted information that provides patients with an understanding of the importance of participation in leadership rounding and how it will provide support and improved care. 
This project's focus was to have a sustainable specific population and macrosystem level change in the organization. The project involves healthcare professionals and patients from multispecialty clinics. The long-term effect of this project is for leadership rounding to be rolled out to many different ambulatory clinics and multiple sites across the broader organization. While this was not possible immediately after the project implementation, due to COVID-19 barriers, it is still planned. There is also potential to develop a new standard for pediatric ambulatory care rounding as the literature lacks this population area.

The SWOT analysis (see Appendix C) was completed for the ambulatory department and leadership rounding before implementation. Strengths at the time of the analysis, which was in the fall of 2020, included staff having a strong ethos for openness, commitment to patient satisfaction, and families being confident in the care received. Leadership rounding is already being supported and completed in the institution with established technology such as Rounds+ and smartphones. The Rounds+ software program records the patient's responses to the leadership rounding survey questions (see Appendix D). There were weaknesses identified, including inconsistencies in patient satisfaction scores for departments, staffing issues, and limitations on in person appointments due to COVID-19 restrictions. These limitations have increased the use of telehealth and eliminated nursing from these visits as patients often call directly to speak to the provider. Opportunities that exist include increasing patient satisfaction scores and improving community trust, with potentially higher clinic ratings for clinics that are lower performers. Another opportunity is the potential of financial savings and meeting national standards for Magnet and the American Nurses Association. Utilizing the Rounds+ platform is also an opportunity to advance technology use. The external threats to this department and project are economic slowdown, COVID-19 restrictions, altered communication due to 
facemasks, insurance changes, and resistance to rounding from staff and patients. There are reported prior challenges to access data with NRC and Rounds+ data in a timely manner, and rounding outcomes can be challenging to quantify and put into statistical measures. This project's main objectives (see appendix F for all objectives) were to improve the overall patient satisfaction scores, increase nursing respect, and care team communication through reported percentage numbers from NRC surveys, in two ambulatory clinics for 4 weeks after the implementation of leadership rounding.

\section{Implementation Plan with Timeline and Budget}

\section{Implementation Schedule}

These aims will be accomplished following the JHNEBP process and using Kotter's Change Theory. Following the JHNEBP, after the evidence was collected, the project moved into the translation phase, with stakeholders being notified and support was sought. Under Kotter's Change Process, the vision of the project was communicated, and buy-in was obtained. The project leader obtained the support of the directors for ambulatory medicine, as well as other stakeholders. Implementation started in August 2021, after the approval from the University of St. Augustine for Health Sciences Doctor of Nursing Practice Evidence-Based Practice Review Council (EPRC) review and the hospital's Evidence Based Practice/Quality Improvement (EBP/QI) Council committee. See Appendix E for more detail on the schedule for this project.

Rounds+ software has the leadership rounding survey questions loaded into the program and records patient responses for data collection. The implementation period lasted 4 weeks. The rounding during the 4 week period, aimed to collect at least 20 to 25 patients and family responses, using the leadership rounding survey questions for each family. This goal was established using the current handwashing surveys aim. This aim is so that both surveys can be 
combined for efficiency and sustainability. The rounding is a modified intentional rounding survey adapted to the ambulatory care setting from the current rounding tools used at the facility (see Appendix D). These leadership rounding surveys have been in use for several years and have face validity, as leaders have used them for some time. The surveys are widely accepted in the hospital in multiple departments, including emergency and urgent care outpatient settings, inpatient settings, and general use. The survey length was a challenge in the ambulatory setting and has been condensed for sustainability.

The directors of the ambulatory departments and nursing research department have all verified face validity for the survey. The leadership survey has been shown to have value by increasing patient experience knowledge. Two weeks into the intervention, the data from Rounds+ was tabulated, and the goal of a minimum of 20 rounds per clinic was obtained at this time. NRC reported patient satisfaction results once a month and was collected at the beginning of September 2021. The project manager collaborated in this data collection with the patientfamily experience chair for ambulatory patients who has access to the data management program in Rounds+. The intervention was completed at the end of August 2021, and the final data collection points were collected the second week of September 2021. After collecting the NRC survey data and Leadership Survey data from the Rounds+ application, the data was analyzed and summarized for final evaluation and dissemination.

\section{Budget}

The budget for this project was minimal outside of the standard operating cost, and the directors approved the hospital's cost (see Table 1). At the end of this project, the cost for hospital-employed leaders was deleted as there were no ambulatory leaders who completed rounds and needed approved time for this activity. There was also no need for celebrations on the 
unit as the project leader did the rounds. Hospital costs included time with the patient satisfaction team and the Rounds+ representative to build the survey and train the project leader on the use of the instrument. Other budget expenses included a statistician for the analysis of the data before dissemination.

\section{Role of the Project Leader}

Throughout this project's phases, the project leader was involved in all aspects. Using Kotter's Change Process, the project started creating urgency and building momentum with the investment of a strong team. Transformational leadership skills align with the hospitals' values and is also supported by the American Nurses Credentialing Center and Magnet designation as required skills for EBP implementation (Everett \& Sitterding, 2010). These skills include serving on interdisciplinary teams, including nurses, physicians, healthcare aides, patient family experience representatives, parents, and unit service specialists. A high-level system change requires a team of stakeholders and support from multiple disciplines. The project leader was responsible for updating the stakeholders regularly throughout the process. This communication was done with bi-monthly and monthly emails that consisted of critical updates as the project moved forward post approval from key stakeholders. The responsibilities also included ensuring the staff implemented the leader rounding and that it was completed as defined in the project. At the end of the implementation period, it was vital to perform a complete evaluation. The project's summary and the review of outcomes were delivered to key stakeholders by the project leader.

\section{Results}

NRC Health was the survey tool used by this healthcare facility to evaluate patient satisfaction. This measurement tool is used to track patient behaviors, preferences, wants, and needs (NRC Health, n.d.). The NRC survey was delivered by NRC staff, after a patient had 
completed a visit in the ambulatory care department and included questions about the responsiveness of the hospital staff, nursing communication, pain management, cleanliness, and patient education. The responses to the survey were reported monthly to the hospital and directors of the departments. This data was also posted on the hospital's internal SharePoint website. The overall patient satisfaction scores were reported and recorded by clinic name in the percentage of those surveyed who reported a 9/10 score. For reporting and running Chi-squared testing on data, the rate of patients reported a 9/10 was listed as a yes, and those who did not give the top rating were a no for the statistical analysis. Data from the $\mathrm{CHC}$ and DHI clinics were used and compared in this pilot project. This data was de-identified information from the NRC survey and was collected directly by NRC and then reported to the hospital with the satisfaction scores in aggregate form. The inclusion criteria were all patients or families who returned the survey to the NRC. The questions compiled from the NRC reports were "satisfaction with provider; would recommend facility; confidence and trust in nurses and nurses listened carefully." These scores were compared to pre-and post-intervention data collection.

The project leader completed the leadership rounding for both pilot clinics, resulting in 21 rounding surveys conducted per clinic. This number met the minimum process measure goal of 20 per clinic during August 2021. Due to the unprecedented strains of the COVID-19 pandemic on the healthcare system and staffing in the hospital system, the nurse unit leaders could not implement the intervention themselves; therefore, the project leader stepped in to complete the leadership rounding. Although the nurse unit leaders were available if any patient concerns arose, the outcome measure for nurse leader satisfaction related to the rounding process could not be obtained, due to this change. The total number of leadership rounds completed was recorded in Rounds+ and saved in the system. Only pre-approved users can access this data with 
a password. This collected information was retrieved from Rounds+ and saved on a passwordprotected hard drive in aggregate form with no patient identifiers for data analysis.

The data analysis was done using the collected data from the NRC report and leadership rounding surveys. The NRC tool is valid and reliable and is used in hospitals across the country. The collected measures are reviewed in Appendix F, including the goals for the measures, the statistical test used, and the type of data collected. Due to the small size group, nonparametric equality of medians tests or $\chi 2$ (chi-squared) tests were conducted to compare each variable's pre-and post-groups; additionally, $p$-values of .05 or less are considered significant. Data analysis was performed with Intellectus Statistics online software (Intellectus Statistics, 2021).

Qualitative data collected from the Rounds+ Leadership Surveys was evaluated for themes and reported descriptively.

The primary outcome measure was to determine if this intervention of leadership rounding improved patient satisfaction as measured by four satisfaction questions. The chisquare test results were not significant based on an alpha value of 0.05 , with $p$-values reported in Table 2 for both pre-and post-intervention clinics. These results imply that the observed frequencies were not significantly different than the expected frequencies. Table 2 presents the results of the chi-square test for both clinics and the pre-and post-data collection.

Table 2

NRC Survey Results from Pre-Post Intervention

\begin{tabular}{|l|l|l|l|l|l|l|}
\hline & \multicolumn{2}{|l|}{ Digestive Health } & \multicolumn{2}{l|}{ Child Health } \\
\hline & Pre (July) & Post (Aug) & p-value* & Pre (July) & Post (Aug) & p-value* \\
\hline $\begin{array}{l}\text { Provider } \\
\text { Satisfaction }\end{array}$ & $\begin{array}{l}92(87.6 \%) \\
(\mathrm{N}=105)\end{array}$ & $\begin{array}{l}83(85 \%) \\
(\mathrm{N}=95)\end{array}$ & 0.957 & $\begin{array}{l}70(76.9 \%) \\
(\mathrm{N}=90)\end{array}$ & $\begin{array}{l}105(81 \%) \\
(\mathrm{N}=124)\end{array}$ & 0.416 \\
\hline
\end{tabular}




\begin{tabular}{|l|l|l|l|l|l|l|}
\hline $\begin{array}{l}\text { Would } \\
\text { recommend } \\
\text { facility }\end{array}$ & $\begin{array}{l}55(91.7 \%) \\
(\mathrm{N}=60)\end{array}$ & $\begin{array}{l}43(87.8 \%) \\
(\mathrm{N}=49)\end{array}$ & 0.500 & $\begin{array}{l}55(81.7 \%) \\
(\mathrm{N}=67)\end{array}$ & $\begin{array}{l}91(83.5 \%) \\
(\mathrm{N}=109)\end{array}$ & 0.811 \\
\hline $\begin{array}{l}\text { Confidence } \\
\text { and trust in } \\
\text { nurses }\end{array}$ & $\begin{array}{l}56(87.5 \%) \\
(\mathrm{N}=64)\end{array}$ & $\begin{array}{l}43(87.8 \%) \\
(\mathrm{N}=49)\end{array}$ & 0.967 & $\begin{array}{l}61(65.6 \%) \\
(\mathrm{N}=93)\end{array}$ & $\begin{array}{l}75(71.4 \%) \\
(\mathrm{N}=105)\end{array}$ & 0.696 \\
\hline $\begin{array}{l}\text { Nurses } \\
\text { listened } \\
\text { carefully }\end{array}$ & $\begin{array}{l}57(87.7 \%) \\
(\mathrm{N}=65)\end{array}$ & $\begin{array}{l}46(90.2 \%) \\
(\mathrm{N}=51)\end{array}$ & 0.671 & $\begin{array}{l}64(67.4 \%) \\
(\mathrm{N}=95)\end{array}$ & $\begin{array}{l}75(65.8 \%) \\
(\mathrm{N}=114)\end{array}$ & 0.810 \\
\hline
\end{tabular}

Note: *p-value calculated by Chi-Square Test

The results are consistent with historical data for the different clinics, as the DHI clinic has consistently performed higher than the $\mathrm{CHC}$ clinic. The chi-square test results compared the clinic's pre-and post-intervention data and were significant based on an alpha value of 0.05 , with $p$-values as reported in Table 3.

\section{Table 3}

NRC Survey Results, Pre-Post Intervention, Clinics Compared

\begin{tabular}{|c|c|c|c|c|c|c|}
\hline & \multicolumn{3}{|l|}{ Clinics Pre } & \multicolumn{3}{|l|}{ Clinics Post } \\
\hline & $\begin{array}{l}\text { Digestive } \\
\text { Health } \\
\text { July }\end{array}$ & $\begin{array}{l}\text { Child } \\
\text { Health } \\
\text { July }\end{array}$ & p-value* & $\begin{array}{l}\text { Digestive } \\
\text { Health } \\
\text { Aug }\end{array}$ & $\begin{array}{l}\text { Child } \\
\text { Health } \\
\text { Aug }\end{array}$ & p-value* \\
\hline $\begin{array}{l}\text { Confidence } \\
\text { and trust in } \\
\text { nurses }\end{array}$ & $\begin{array}{l}56(87.5 \%) \\
(\mathrm{N}=64)\end{array}$ & $\begin{array}{l}61(65.6 \%) \\
(\mathrm{N}=93)\end{array}$ & 0.002 & $\begin{array}{l}43(87.8 \%) \\
(\mathrm{N}=49)\end{array}$ & $\begin{array}{l}75(71.4 \%) \\
(\mathrm{N}=105)\end{array}$ & 0.026 \\
\hline $\begin{array}{l}\text { Nurses } \\
\text { listened } \\
\text { carefully }\end{array}$ & $\begin{array}{l}57(87.7 \%) \\
(\mathrm{N}=65)\end{array}$ & $\begin{array}{l}64(67.4 \%) \\
(\mathrm{N}=95)\end{array}$ & .003 & $\begin{array}{l}46(90.2 \%) \\
(\mathrm{N}=51)\end{array}$ & $\begin{array}{l}75(65.8 \%) \\
(\mathrm{N}=114)\end{array}$ & 0.001 \\
\hline
\end{tabular}

These continued differences suggest practice differences between clinics and that the leadership rounding could improve scores and ensure consistency. Other outcome measures 
reported on the leadership rounding survey included the percentage of patients and families reporting that they received great care and that the communication between team members was consistent; both pilot clinics reported $100 \%$ satisfaction. Statistical analysis was not needed for these measures. This outcome met both goals for the leadership rounding data measures.

The clinical significance of improvements related to leadership rounding can be associated with the visual and qualitative information collected during data collection. This information can be used to improve processes and care for patients. One of the observed differences between DHI and CHC was that a nurse completed an intake questionnaire before the provider visit in the DHI clinic, but this was not observed in the $\mathrm{CHC}$ clinic. Another difference was that a nurse was assigned to all patients who received leadership rounding; however, many of the patients in the $\mathrm{CHC}$ clinic did not see a nurse for extended time frames or at all. These differences in nurse involvement could explain one area that impacts the nursing-related questions on the NRC survey. During leadership rounding, themes emerged when patients and families were asked if there were any recommendations or kudos to the team. Patients and families in the DHI clinic reported being seen early and that this was the best clinic they have ever been to, including other clinics at the same facility. Comments from families in the DHI included, "We have been to a lot of clinics, and DHI is the best managed and well run of them all" and "today has been great, we saw neuro last week and had to wait over two hours, so it was nice to get in and be seen on time today." It was typical for the $\mathrm{CHC}$ clinic to hear praise from several families and complaints that the clinic often ran behind. One comment on this was, "It would be nice to have an update to reduce anxiety (while waiting)." No current complaints needed addressing during the rounding process; however, a few recommendations were made that have been passed on to the nurse unit leaders. These recommendations include; a request to 
schedule more than two siblings at the same time for checkups; confirmation texts to include all children in the appointment; letting families bring siblings into the room as they sometimes do not have a choice but to bring them; adding a check-in option for non-binary patients, so they do not have to select "other"; and more translators in person.

\section{Impact}

While statistical significance was not observed for the outcome measures, the clinical importance will address the shared patient concerns that were shared to improve patient and family satisfaction moving forward. Additionally, addressing the continued perceived differences from one clinic to the next can impact the perceived quality of care in the long run. The local community trusts that they will receive extraordinary evidence-based care when seen at any of the clinics within the organization. By comparing data between clinics, the lessons learned from one clinic to the next can be shared throughout the organization for consistency. For example, DHI has a nurse enter the room and perform an intact questionnaire; this initial contact and communication with a nurse can impact a patient's perception of nursing care. This practice is not done in the $\mathrm{CHC}$ clinic and could contribute to why nursing care is statistically lower for this clinic.

Since the initiation of this project, the face of healthcare has significantly changed because of the worldwide pandemic of the COVID-19 virus. A limitation of the project was that more patients were being seen remotely, which was not captured in the project design. Staffing within the entire facility has been dramatically impacted due to COVID-19, and fewer nurse leaders are available to perform rounding with families. It was necessary to have the project leader implement the rounding instead of clinic nursing leaders due to these limitations. Another constraint was that patient satisfaction only includes the highest satisfaction scores and only 
families who take the time to fill the survey out. Families that were rounded on may not have completed the NRC post-visit survey and would not have been captured in the overall satisfaction for units. A further limitation, that will also have an effect on sustainability, was that the clinics in the organization do not all function the same, which will have an impact on rounding and patient satisfaction results.

The project's sustainability is that the leadership rounding survey has been created, and the ambulatory directors want to initiate this survey. The survey is readily available for use in Rounds+ when staffing issues are resolved, and clinic leaders have the availability to resume rounding. This project was a pilot project for only two clinics, but with many more clinics in the institution, the directors of ambulatory care want to see this rounding expanded to the other clinics. The survey only takes about two minutes to complete, which helps with the sustainability for a busy clinic leader. This time frame makes it possible for nurse leaders to round on several families in a short window of time each month. Clinic managers already pull patient satisfaction surveys monthly, and evaluation of the satisfaction surveys can be compared once the rounding is resumed. However, a barrier to sustainability is that the new staff hired to correct the current staff shortage will not be familiar with the project and may not have the same investment as the project team. There would need to be training and orientation to the tool once staff is hired for these leadership roles and project sustainability. Another barrier is that due to this project's limitations, statistical significance was not observed, and the lack of supporting data could limit future buy-in from staff.

\section{Dissemination Plan}

Getting staff buy-in long-term will be impacted by appropriately disseminating the information to others. The project's findings were disseminated to the ambulatory directors. The 
meeting was done via a virtual meeting with the directors from both clinics. This meeting included the project overviews, such as the time it took to complete the surveys and the results obtained. Plans for sustainability and rolling out the leadership rounding to all units have been placed on hold due to significant staffing shortages in all ambulatory clinics secondary to COVID-19's impact on healthcare. However, the clinic directors see the value and have buy-in for future implementation of the leadership rounding tool in the near future.

Publication of the project work and findings, while not statistically significant, can be used for other nurses to learn from challenges in implementing a project during a healthcare crisis. This project and the lessons learned from the challenges faced were presented at the University of St. Augustine's for Health Sciences Sigma Theta Tau chapter meeting in November 2021. Areas of potential future publication could be in the Society of Pediatric Nurses Professional Journal, the Beryl Institute's annual conference, and The Rounds + Software Journal. The Beryl Institute's Patient Experience Journal is an appropriate choice for potential publication as it is a peer-reviewed journal focusing on expanding global evidence regarding patient experience. Project publication is also included in the Soar@USA database, a collection of all student and faculty work at the University.

\section{Conclusion}

The patient experience is one of the four focal points of improving patient care, as stated in the Quadruple aim (IHI, 2020). Poor patient satisfaction has been linked to challenges with outcomes and retaining patients, and it can impact a facility's finances and the patient's health. Implementation of leadership rounding is one method for improving patient satisfaction. Seeing how a visit is going for a family during leadership rounding and intervening on any family needs immediately can quickly resolve poor experiences. Leadership has the respect to make a positive 
impression and correct any issues that might lead to a poor patient experience. Performing consistent weekly leadership rounding can improve the patient experience by addressing these concerns. Leadership rounding can also help departments recognize patient identified concerns related to the facility, care, and processes. Nurse leaders are able to address both immediate and long-term needs that patients and families are concerned about in the clinic. The JHNEBP model and Kotter's Theory of change were guides for the implementation of this project. Through the guidance of the project leader, the ambulatory department at a children's facility was able to identify several key factors that needed to be addressed. The value in leadership rounding might not be consistently verified in numbers but is demonstrated through patient perceptions and the improvement of the patient experience through consistent communication and care between departments. 


\section{References}

Agency for Healthcare Research and Quality. (2017). CAHPS ambulatory care improvement guide.

https://www.ahrq.gov/sites/default/files/wysiwyg/cahps/qualityimprovement/improvemen t-guide/2-why-improve/cahps-section-2-why-improve-patientexperience.pdf

Agency for Healthcare Research and Quality. (2017, December). Strategy 2: Communicating to improve quality. Retrieved October 30, 2020, from https://www.ahrq.gov/patientsafety/patientsfamilies/engagingfamilies/strategy2/index.html

American Nurses Credentialing Center. (n.d.). Why become Magnet? American Nurses Association. Retrieved October 13, 2020, from https://www.nursingworld.org/organizational-programs/magnet/aboutmagnet/whybecome-magnet/

Ayaad, O., Alloubani, A., Al-rafaay, M., Arideh, A., Abualeish, M., \& Akhu-Zaheya, L. (2019). Impact of structured nurse leader rounds on satisfaction with nursing care among patients with cancer. Journal of Nursing Scholarship, 51(5), 526-536. https://doi.org/10.1111/jnu.12503

Barrow, J. M., Annamaraju, P., \& Toney-Butler, T. J. (2021). Change management. StatPearls. https://www.ncbi.nlm.nih.gov/books/NBK459380/

Bitzer, E., Volkmer, S., Petrucci, M., Weissenrieder, N., \& Dierks, M.-L. (2012). Patient satisfaction in pediatric outpatient settings from the parents' perspective - the Child ZAP: A psychometrically validated standardized questionnaire. BMC Health Services Research, 12(1). https://doi.org/10.1186/1472-6963-12-347 
Children's Hospital Colorado. (2015). It's a threepeat! We achieved nursing's highest honor for the third time. https://www.childrenscolorado.org/about/news/2015/december2015/magnet-redesignation/

Children's Hospital Colorado. (2021). Patient-family experience at Children's Hospital Colorado. Retrieved April 17, 2021, from https://www.childrenscolorado.org/about/quality/patientexperience/

Cody, R., \& Williams-Reed, J. (2018). Intentional nurse manager rounding and patient satisfaction. Nursing Management, 49(4), 16-19. https://doi.org/10.1097/01.numa.0000531172.62599.ba

Dang, D., \& Dearholt, S. (2018). Johns Hopkins nursing evidence-based practice: Model and guidelines (3rd ed.). Sigma Theta Tau International.

Davis, J., Burrows, J. F., Ben Khallouq, B., \& Rosen, P. (2017). Predictors of patient satisfaction in pediatric oncology. Journal of Pediatric Oncology Nursing, 34(6), 435-438. https://doi.org/10.1177/1043454217717239

East, L., Targett, D., Yeates, H., Ryan, E., Quiddington, L., \& Woods, C. (2020). Nurse and patient satisfaction with intentional rounding in a rural Australian setting. Journal of Clinical Nursing, 29(7-8), 1365-1371. https://doi.org/10.1111/jocn.15180

Everett, L. Q., \& Sitterding, M. (2010). Transformational leadership required to design and sustain evidence-based practice: A system exemplar. Western Journal of Nursing Research, 33(3), 398-426. https://doi.org/10.1177/0193945910383056

Flowers, K., Wright, K., Langdon, R., McIlwrath, M., Wainwright, C., \& Johnson, M. (2016). Intentional rounding: Facilitators, benefits and barriers. Journal of Clinical Nursing, 25(9-10), 1346-1355. https://doi.org/10.1111/jocn.13217 
Gamble, M. (2012, April 30). 30 statistics on global patient satisfaction. Becker's Hospital Review. https://www.beckershospitalreview.com/hospital-managementadministration/30$\underline{\text { statistics-on-global-patient-satisfaction.html }}$

Harrington, A., Bradley, S., Jeffers, L., Linedale, E., Kelman, S., \& Killington, G. (2013). The implementation of intentional rounding using participatory action research. International Journal of Nursing Practice, 19, 523-529. https://doi.org/10.1111/ijn.12101

Haskard Zolnierek, K. B., \& DiMatteo, M. (2009). Physician communication and patient adherence to treatment: A meta-analysis. Medical Care, 47(8), 826-834. https://doi.org/10.1097/mlr.0b013e31819a5acc

Institute for Healthcare Improvement. (2020). Triple aim for populations. Retrieved September 27, 2020, from http://www.ihi.org/Topics/TripleAim/Pages/Overview.aspx

Intellectus Statistics. (2021). Intellectus Statistics [Online software]. https://analyze.intellectusstatistics.com/

Kirk, K., \& Kane, R. (2016). A qualitative exploration of intentional nursing round models in the emergency department setting: Investigating the barriers to their use and success. Journal of Clinical Nursing, 25(9-10), 1262-1272. https://doi.org/10.1111/jocn.13150

Kotter, J. P. (2012). Leading change (1st ed.). Harvard Business Review Press.

Larson, E., Sharma, J., Bohren, M. A., \& Tunçalp, Ö. (2019). When the patient is the expert: Measuring patient experience and satisfaction with care. Bulletin of the World Health Organization, 97(8), 563-569. https://doi.org/10.2471/blt.18.225201

Levinson, W. (1997). Physician-patient communication. The relationship with malpractice claims among primary care physicians and surgeons. The Journal of the American Medical Association, 277(7), 553-559. 
Meade, C. M., Bursell, A. L., \& Ketelsen, L. (2006). Effects of nursing rounds: On patients' call light use, satisfaction, and safety. American Journal of Nursing, 106(9), 58-70. https://doi.org/10.1097/00000446-200609000-00029

Melnyk, B. M., \& Fineout-Overholt, E. (2019). Evidence-based practice in nursing \& healthcare: A guide to best practice (4th ed.). Wolters Kluwer.

NRC Health. (n.d.). Our purpose. https://nrchealth.com/our-purpose/

Ogbolu, Y., Scrandis, D. A., Fitzpatrick, G., \& Newhouse, R. (2016). Leading organizational cultural competency. JONA: The Journal of Nursing Administration, 46(12), 627-629. https://doi.org/10.1097/nna.0000000000000417

Prakash, B. (2010). Patient satisfaction. Journal of Cutaneous and Aesthetic Surgery, 3(3), 151. https://doi.org/10.4103/0974-2077.74491

Press Ganey. (2017). The pediatric patient experience: One size does not fit all. Retrieved April 17, 2021, from https://www.pressganey.com/resources/articles/the-pediatricpatientexperience-one-size-does-not-fit-all

Rea, K. E., Rao, P., Hill, E., Saylor, K. M., \& Cousino, M. K. (2018). Families’ experiences with pediatric family-centered rounds: A systematic review. Pediatrics, 141(3), e20171883. https://doi.org/10.1542/peds.2017-1883

Rondinelli, J., Ecker, M., Crawford, C., Seelinger, C., \& Omery, A. (2012). Hourly rounding implementation: A multisite description of structures, processes, and outcomes. JONA: The Journal of Nursing Administration, 42(6), 326-332. https://doi.org/10.1097/nna.0b013e31824ccd43

Shin, N., \& Park, J. (2018). The effect of intentional nursing rounds based on the care model on patients' perceived nursing quality and their satisfaction with nursing services. Asian 
Nursing Research, 12(3), 203-208. https://doi.org/10.1016/j.anr.2018.08.003

Tan, M., \& Lang, D. (2015). Effectiveness of nurse leader rounding and post-discharge telephone calls in patient satisfaction: A systematic review. JBI Database of Systematic Reviews and Implementation Reports, 13(7), 154-176. https://doi.org/10.11124/jbisrir$\underline{2015-2013}$

Vitals. (2018, March 22). 9th annual vitals wait time report released. Business Wire. https://www.businesswire.com/news/home/20180322005683/en/9th-Annual-Vitals$\underline{\text { WaitTime-Report-Released }}$

\section{Table 1}

Budget 


\begin{tabular}{|c|r|l|c|}
\hline \multicolumn{1}{|l|}{ Direct } & Billing & \\
\hline $\begin{array}{l}\text { Salary for Rounds+ } \\
\text { representative in hospital } \\
\text { (4hrs for developing } \\
\text { questions) }\end{array}$ & $\$ 200$ & Institutional budget support & $\$ 200$ \\
\hline Project Leader & $\$ 0$ & & \\
\hline Services & $\$ 100$ & & \\
\hline Statistician & $\mathbf{\$ 1 0 0}$ & & $\mathbf{\$ 2 0 0}$ \\
\hline Celebration supplies & $\mathbf{\$ 4 0 0}$ & Total Revenue & \\
\hline Total Expenses & $\mathbf{- \$ 2 0 0}$ & & \\
\hline Net Balance & & & \\
\hline
\end{tabular}

\section{Table 2}

NRC Survey Results from Pre-Post Intervention

\begin{tabular}{|l|l|l|l|l|l|l|}
\hline & \multicolumn{3}{|l|}{ Digestive Health } & \multicolumn{2}{l|}{ Child Health } \\
\hline & Pre (July) & Post (Aug) & p-value* & Pre (July) & Post (Aug) & p-value* \\
\hline $\begin{array}{l}\text { Provider } \\
\text { Satisfaction }\end{array}$ & $\begin{array}{l}92(87.6 \%) \\
(\mathrm{N}=105)\end{array}$ & $\begin{array}{l}83(85 \%) \\
(\mathrm{N}=95)\end{array}$ & 0.957 & $\begin{array}{l}70(76.9 \%) \\
(\mathrm{N}=90)\end{array}$ & $\begin{array}{l}105(81 \%) \\
(\mathrm{N}=124)\end{array}$ & 0.416 \\
\hline $\begin{array}{l}\text { Would } \\
\text { recommend } \\
\text { facility }\end{array}$ & $\begin{array}{l}55(91.7 \%) \\
(\mathrm{N}=60)\end{array}$ & $\begin{array}{l}43(87.8 \%) \\
(\mathrm{N}=49)\end{array}$ & 0.500 & $\begin{array}{l}55(81.7 \%) \\
(\mathrm{N}=67)\end{array}$ & $\begin{array}{l}91(83.5 \%) \\
(\mathrm{N}=109)\end{array}$ & 0.811 \\
\hline $\begin{array}{l}\text { Confidence } \\
\text { and trust in } \\
\text { nurses }\end{array}$ & $\begin{array}{l}56(87.5 \%) \\
(\mathrm{N}=64)\end{array}$ & $\begin{array}{l}43(87.8 \%) \\
(\mathrm{N}=49)\end{array}$ & 0.967 & $\begin{array}{l}61(65.6 \%) \\
(\mathrm{N}=93)\end{array}$ & $\begin{array}{l}75(71.4 \%) \\
(\mathrm{N}=105)\end{array}$ & 0.696 \\
\hline $\begin{array}{l}\text { Nurses } \\
\text { listened } \\
\text { carefully }\end{array}$ & $\begin{array}{l}57(87.7 \%) \\
(\mathrm{N}=65)\end{array}$ & $\begin{array}{l}46(90.2 \%) \\
(\mathrm{N}=51)\end{array}$ & 0.671 & $\begin{array}{l}64(67.4 \%) \\
(\mathrm{N}=95)\end{array}$ & $\begin{array}{l}75(65.8 \%) \\
(\mathrm{N}=114)\end{array}$ & 0.810 \\
\hline
\end{tabular}

Note: *p-value calculated by Chi-Square Test 
Table 3

NRC Survey Results, Pre-Post Intervention, Clinics Compared

\begin{tabular}{|l|l|l|l|l|l|l|}
\hline \multicolumn{3}{|l|}{ Clinics Pre } & \multicolumn{2}{l|}{ Clinics Post } \\
\hline & $\begin{array}{l}\text { Digestive } \\
\text { Health } \\
\text { July }\end{array}$ & $\begin{array}{l}\text { Child } \\
\text { Health } \\
\text { July }\end{array}$ & p-value* & $\begin{array}{l}\text { Digestive } \\
\text { Health } \\
\text { Aug }\end{array}$ & $\begin{array}{l}\text { Child } \\
\text { Health } \\
\text { Aug }\end{array}$ & p-value* \\
\hline $\begin{array}{l}\text { Confidence } \\
\text { and trust in } \\
\text { nurses }\end{array}$ & $\begin{array}{l}56(87.5 \%) \\
(\mathrm{N}=64)\end{array}$ & $\begin{array}{l}61(65.6 \%) \\
(\mathrm{N}=93)\end{array}$ & 0.002 & $\begin{array}{l}43(87.8 \%) \\
(\mathrm{N}=49)\end{array}$ & $\begin{array}{l}75(71.4 \%) \\
(\mathrm{N}=105)\end{array}$ & 0.026 \\
\hline $\begin{array}{l}\text { Nurses } \\
\text { listened } \\
\text { carefully }\end{array}$ & $\begin{array}{l}57(87.7 \%) \\
(\mathrm{N}=65)\end{array}$ & $\begin{array}{l}64(67.4 \%) \\
(\mathrm{N}=95)\end{array}$ & .003 & $\begin{array}{l}46(90.2 \%) \\
(\mathrm{N}=51)\end{array}$ & $\begin{array}{l}75(65.8 \%) \\
(\mathrm{N}=114)\end{array}$ & 0.001 \\
\hline \begin{tabular}{l} 
*p-value calculated by Chi-Square Test \\
\hline
\end{tabular}
\end{tabular}




\section{Figure 1}

PRISMA chart

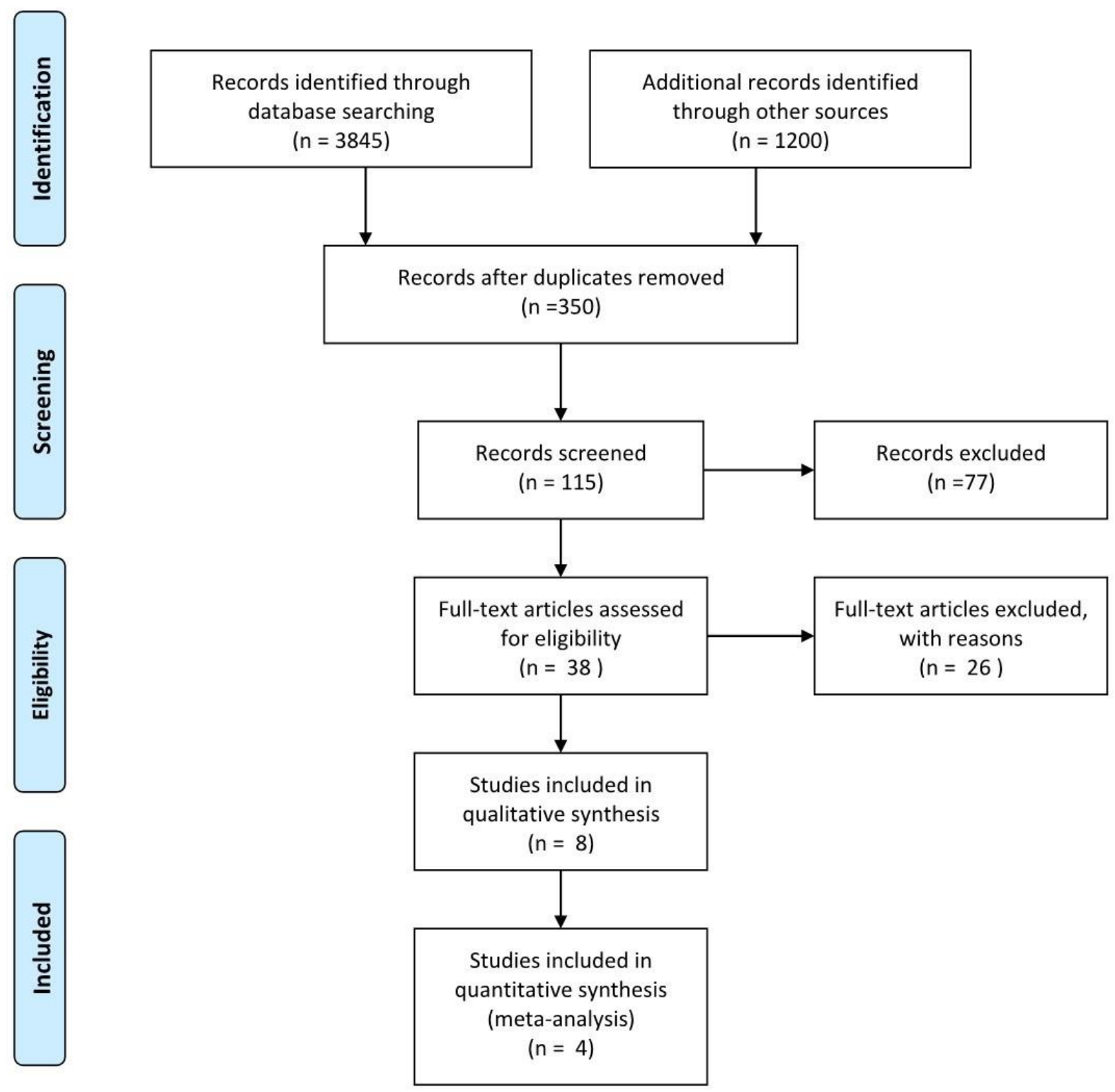


Primary Research Evidence

\begin{tabular}{|c|c|c|c|c|c|c|}
\hline Citation & $\begin{array}{c}\text { Design, } \\
\text { Level } \\
\text { Quality } \\
\text { Grade }\end{array}$ & $\begin{array}{c}\text { Sample } \\
\text { Sample size }\end{array}$ & $\begin{array}{c}\text { Intervention } \\
\text { Comparison } \\
\text { (Definitions should } \\
\text { include any specific } \\
\text { research tools used } \\
\text { along with } \\
\text { reliability \& } \\
\text { validity) }\end{array}$ & $\begin{array}{l}\text { Theoretical } \\
\text { Foundation }\end{array}$ & $\begin{array}{c}\text { Outcome } \\
\text { Definition }\end{array}$ & $\begin{array}{c}\text { Usefulness } \\
\text { Results } \\
\text { Key Findings }\end{array}$ \\
\hline $\begin{array}{l}\text { Ayaad, O., Alloubani, A., } \\
\text { Al-rafaay, M., Arideh, A., } \\
\text { Abualeish, M., \& } \\
\text { AkhuZaheya, L. (2019). } \\
\text { Impact of structured nurse } \\
\text { leader rounds on } \\
\text { satisfaction with nursing } \\
\text { care among patients with } \\
\text { cancer. Journal of Nursing } \\
\text { Scholarship, 51(5), 526- } \\
\text { 536. } \\
\underline{\text { https://doi.org/10.1111/jnu. }} \\
\underline{12503}\end{array}$ & $\begin{array}{l}\text { RCT } \\
\text { Level IA }\end{array}$ & $\begin{array}{l}\text { total of } 190 \\
\text { patients } \\
\text { participated in the } \\
\text { study to overcome } \\
\text { the effects of } \\
\text { participants } \\
\text { withdrawing from } \\
\text { the study } \\
\text { Inclusion criteria; } \\
\text { patients diagnosed } \\
\text { with cancer, } 18 \\
\text { years of age and } \\
\text { older, conscious, } \\
\text { oriented to the } \\
\text { nursing care, and } \\
\text { hospitalized in } \\
\text { one of the four } \\
\text { units for at least } 3 \\
\text { days. Exclusion } \\
\text { criteria were } \\
\text { patients }\end{array}$ & $\begin{array}{l}\text { Patient satisfaction } \\
\text { was measured using } \\
\text { the Patient } \\
\text { Satisfaction with } \\
\text { Nursing Care Quality } \\
\text { Questionnaire, which } \\
\text { was derived from the } \\
\text { Patient Judgement of } \\
\text { Hospital Quality } \\
\text { Questionnaire. } \\
\text { A scripted } 5 \text { min } \\
\text { nurse leader tool was } \\
\text { used to standardize } \\
\text { the structured leader } \\
\text { round as developed } \\
\text { by } \\
\text { Babaev (2015). } \\
\text { Content validity of } \\
\text { the scripted nurse } \\
\text { leader tool was } \\
\text { assessed by five } \\
\text { expert nurse leaders. }\end{array}$ & $\begin{array}{l}\text { Not clearly } \\
\text { defined in } \\
\text { the paper }\end{array}$ & $\begin{array}{l}\text { Impact on } \\
\text { satisfaction with } \\
\text { nursing care among } \\
\text { patients with } \\
\text { cancer=The } \\
\text { questionnaire was } \\
\text { scored per item by } \\
\text { calculating the } \\
\text { means of patients" } \\
\text { responses for each } \\
\text { item using a 5-point } \\
\text { Likert scale (1 to 5), } \\
\text { where a score of } 1 \\
\text { indicated that the } \\
\text { perception of the } \\
\text { item was "poor," } \\
\text { and } 5 \text { indicated the } \\
\text { perception of the } \\
\text { item was } \\
\text { "excellent." A total } \\
\text { score was also } \\
\text { determined as the } \\
\text { sum of the patients' }\end{array}$ & $\begin{array}{l}\text { Significant difference in the } \\
\text { total score of patients' } \\
\text { satisfaction between study } \\
\text { groups }(\mathrm{t}=-9.213, \mathrm{p}> \\
.001) \text {. Conversely, the } \\
\text { structured leader round } \\
\text { significantly impacts the } \\
\text { patient's experience with } \\
\text { nurse concern and caring ( } \mathrm{t}= \\
-2.054, \mathrm{p}=.042) \text {. } \\
\text { NLR has a significant impact } \\
\text { on improving patient } \\
\text { satisfaction in an oncology } \\
\text { setting where patients receive } \\
\text { care from many disciplines, } \\
\text { such as surgical, medical, } \\
\text { radiotherapy, and radiology. }\end{array}$ \\
\hline
\end{tabular}




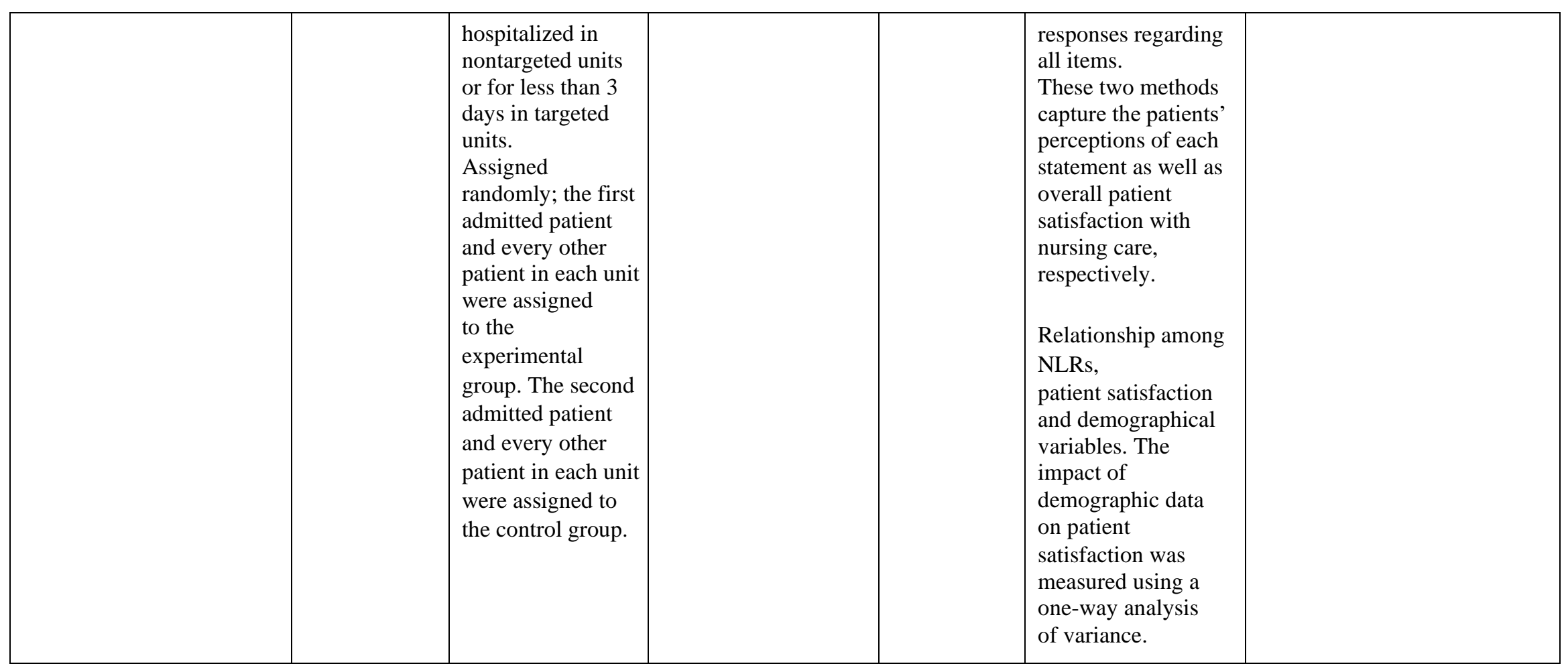




\begin{tabular}{|c|c|c|c|c|c|c|}
\hline $\begin{array}{l}\text { Cody, R., \& WilliamsReed, } \\
\text { J. (2018). Intentional nurse } \\
\text { manager rounding and } \\
\text { patient satisfaction. } \\
\text { Nursing Management } \\
\text { (Springhouse), 49(4), 16- } \\
19 . \\
\text { https://doi.org/10.1097/01. } \\
\text { numa.0000531172.62599.b } \\
\underline{\text { a }}\end{array}$ & $\begin{array}{l}\text { Retrospective } \\
\text { descriptive } \\
\text { study Level } \\
\text { II B }\end{array}$ & $\begin{array}{l}\text { Study participants } \\
\text { were responders } \\
\text { to the HCAHPS } \\
\text { survey from a } \\
\text { period of } 9 \text { months } \\
\text { before the training } \\
\text { and initiation of } \\
\text { intentional nurse } \\
\text { manager rounding } \\
\text { and } 9 \text { months } \\
\text { after the training } \\
\text { and } \\
\text { initiation of } \\
\text { rounding }\end{array}$ & $\begin{array}{l}\text { Nurse Manager } \\
\text { rounding } \\
\text { Intentional questions, } \\
\text { less than } 5 \text { minutes } \\
\text { The HCAHPS survey } \\
\text { questionnaire was the } \\
\text { collection tool. The } \\
\text { surveys were obtained } \\
\text { and reported by an } \\
\text { outside corporation. } \\
\text { This tool has been } \\
\text { validated. }\end{array}$ & $\begin{array}{l}\text { Not clearly } \\
\text { defined }\end{array}$ & $\begin{array}{l}\text { The independent } \\
\text { variable in the study } \\
\text { was the intervention } \\
\text { of nurse manager } \\
\text { rounding. The the } \\
\text { dependent variable } \\
\text { was patient } \\
\text { satisfaction scores } \\
\text { before and after the } \\
\text { intervention. The } \\
\text { scores to be } \\
\text { evaluated were the } \\
\text { overall hospital } \\
\text { rating, the individual } \\
\text { unit rating, and the } \\
\text { nursing bundle }\end{array}$ & $\begin{array}{l}\text { No statistically significant } \\
\text { change in mean patient } \\
\text { satisfaction scores. The only } \\
\text { statistically significant } \\
\text { difference was in response to } \\
\text { one question on Unit B } \\
\text { ("nurses listened carefully to } \\
\text { you") and Unit C ("nurses } \\
\text { explained things in a way you } \\
\text { could understand"), } \\
\text { respectively. The score } \\
\text { for Unit B was } \\
\text { statistically significant in } \\
\text { a negative direction. }\end{array}$ \\
\hline
\end{tabular}

\begin{tabular}{|l|l|l|l|l|l|}
\hline & & & & & related to four \\
specific HCAHPS \\
survey questions: \\
nurses treated you \\
with courtesy and \\
respect, nurses \\
listened carefully to \\
you, nurses \\
explained things in \\
a way you could \\
understand, and you \\
got help as soon as \\
you wanted it.
\end{tabular}




\begin{tabular}{|c|c|c|c|c|c|c|}
\hline $\begin{array}{l}\text { East, L., Targett, D., } \\
\text { Yeates, H., Ryan, E., } \\
\text { Quiddington, L., \& Woods, } \\
\text { C. (2020). Nurse and } \\
\text { patient satisfaction with } \\
\text { intentional rounding in a } \\
\text { rural Australian setting. } \\
\text { Journal of Clinical } \\
\text { Nursing, } 29(7-8), 1365- \\
\text { 1371. } \\
\underline{\text { https://doi.org/10.1111/joc }} \\
\underline{\text { n.15180 }}\end{array}$ & $\begin{array}{l}\text { CrossSectional } \\
\text { quantitative } \\
\text { Levell III-A }\end{array}$ & $\begin{array}{l}\text { Convenience } \\
\text { sampling method } \\
\text { was used to } \\
\text { recruit nurse and } \\
\text { patient } \\
\text { participants from } \\
\text { a rural Australian } \\
\text { hospital. Patients } \\
\text { were eligible to } \\
\text { participate in the } \\
\text { survey if they } \\
\text { were aged } 18 \\
\text { years or older, } \\
\text { had at least an } \\
\text { overnight stay in } \\
\text { the hospital in one } \\
\text { of the selected } \\
\text { wards, } \\
\text { During the data } \\
\text { collection period, } \\
\text { patients in the } \\
\text { hospital were not } \\
\text { ventilated or } \\
\text { cognitively } \\
\text { impaired as }\end{array}$ & $\begin{array}{l}\text { Patient Satisfaction } \\
\text { Survey (PSS) } \\
\text { Responses to each } \\
\text { statement is scored } \\
\text { on a 5-point Likert } \\
\text { scale ranging from } \\
\text { "strongly disagree" } \\
\text { (1) to "strongly } \\
\text { agree" (5) with a } \\
\text { mid-point of } \\
\text { "neutral" (3). } \\
\text { Nurses completed a } \\
\text { modified version of } \\
\text { the PSS. The } \\
\text { questions were } \\
\text { modified to refer to } \\
\text { the care nurses } \\
\text { provide to patients, as } \\
\text { shown in the } \\
\text { following example: } \\
\text { Patient: I was not } \\
\text { kept waiting when I } \\
\text { used my call bell. } \\
\text { Nurse: My patients } \\
\text { are not kept waiting }\end{array}$ & $\begin{array}{l}\text { Evidencebased } \\
\text { leadership } \\
\text { framework }\end{array}$ & $\begin{array}{l}\text { The nurse and } \\
\text { patient versions of } \\
\text { the scale were } \\
\text { summed to create a } \\
\text { total satisfaction } \\
\text { scale. Demographic } \\
\text { data were analyzed } \\
\text { using descriptive } \\
\text { statistics (frequency, } \\
\text { percent, mean, } \\
\text { standard deviation), } \\
\text { and PSS nurse and } \\
\text { patient results were } \\
\text { compared using } \\
\text { independent sample } \\
\text { t-tests. }\end{array}$ & $\begin{array}{l}\text { Intentional rounding practices } \\
\text { ensure that patients feel } \\
\text { genuinely cared for by nursing } \\
\text { staff while hospitalized and } \\
\text { can improve nurse and patient } \\
\text { interactions, satisfaction, and } \\
\text { outcomes } \\
\text { Both nurses and patients were } \\
\text { satisfied with the nursing care } \\
\text { provided and received through } \\
\text { intentional rounding } \\
\text { Patient satisfaction is } \\
\text { predicted by being able to see } \\
\text { a nurse when they needed to, } \\
\text { the provision of pain relief } \\
\text { when needed, feeling } \\
\text { comfortable and safe, and the } \\
\text { perception that nurses were } \\
\text { interested in their feelings } \\
\text { about their care }\end{array}$ \\
\hline
\end{tabular}




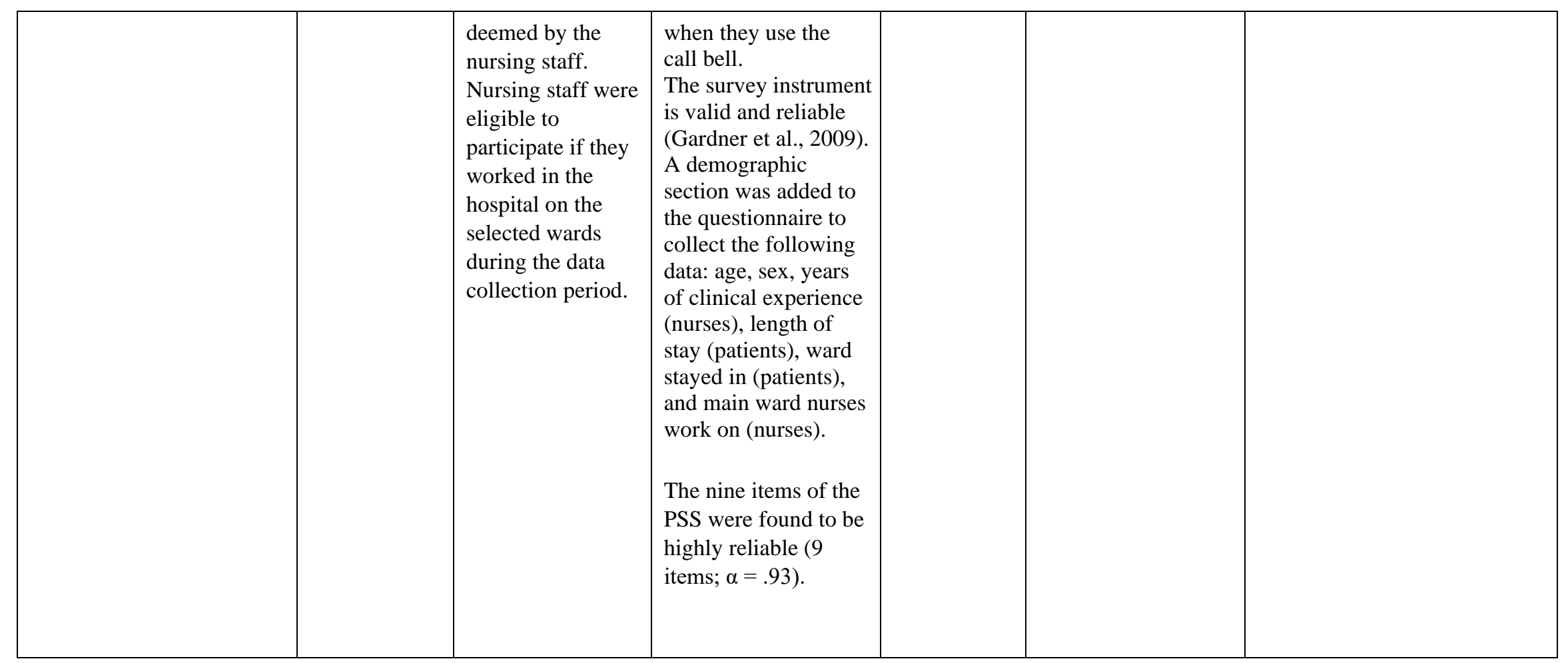




\begin{tabular}{|c|c|c|c|c|}
\hline $\begin{array}{l}\text { Flowers, K., Wright, K., } \\
\text { Langdon, R., McIlwrath, } \\
\text { M., Wainwright, C., \& } \\
\text { Johnson, M. (2016). } \\
\text { Intentional rounding: } \\
\text { Facilitators, benefits, and } \\
\text { barriers. Journal of } \\
\text { Clinical Nursing, 25(9-10), } \\
\text { 1346-1355. } \\
\underline{\text { https://doi.org/10.1111/joc }} \\
\underline{\text { n.13217 }}\end{array}$ & $\begin{array}{l}\text { Descriptive } \\
\text { Qualitative } \\
\text { Level III-A }\end{array}$ & $\begin{array}{l}15 \text { nurses A } \\
\text { convenience } \\
\text { sample of nine } \\
\text { nurses who } \\
\text { responded to an } \\
\text { invitation } \\
\text { extended by the } \\
\text { research team } \\
\text { through the } \\
\text { Nursing/Midwifer } \\
\text { y } \\
\text { Unit Manager } \\
\text { (N/MUM) of their } \\
\text { ward participated } \\
\text { in two focus } \\
\text { groups. A third }\end{array}$ & $\begin{array}{l}3 \text { Focus groups } \\
\text { IR had been } \\
\text { implemented } \\
\text { approximately } 12 \\
\text { months before the } \\
\text { focus groups were } \\
\text { conducted. The focus } \\
\text { groups were digitally } \\
\text { recorded and } \\
\text { transcribed verbatim } \\
\text { for analysis. } \\
\text { Two research team }\end{array}$ & $\begin{array}{l}\text { Engaging all staff, encouraging } \\
\text { ownership, and managing } \\
\text { stability are critical factors in } \\
\text { successfully implementing and } \\
\text { maintaining IR. } \\
\text { IR is flexible and robust } \\
\text { enough to accommodate } \\
\text { different patient types and } \\
\text { acuity. } \\
\text { Patient outcomes associated } \\
\text { with intentional rounding will } \\
\text { vary dependent upon the } \\
\text { clinical setting, with regular } \\
\text { reporting and }\end{array}$ \\
\hline & & $\begin{array}{l}\text { focus group } \\
\text { consisted of six } \\
\text { current and past } \\
\text { N/MUMs and } \\
\text { Clinical } \\
\text { Nurse/Midwifery } \\
\text { Educators } \\
\text { (CN/MEs) from } \\
\text { the participating } \\
\text { wards. }\end{array}$ & $\begin{array}{l}\text { members then } \\
\text { independently } \\
\text { reviewed the data and } \\
\text { identified further } \\
\text { codes. Clustering of } \\
\text { the codes to main and } \\
\text { subthemes occurred. } \\
\text { Textual data analysis } \\
\text { tools such as NVivo } \\
\text { were used to increase } \\
\text { the transparency of } \\
\text { the data analysis. }\end{array}$ & $\begin{array}{l}\text { feedback to nursing staff on } \\
\text { the impact of intentional } \\
\text { rounding on patients being } \\
\text { recommended. } \\
\text { Intentional rounding can be } \\
\text { used as a management tool to } \\
\text { encourage best practices and } \\
\text { accountability for patient care. } \\
\text { Barriers: Some participants felt } \\
\text { the implementation of IR was } \\
\text { an insult to their professional } \\
\text { practice as it may 'take away } \\
\text { from actual patient care.' They } \\
\text { felt the IR tasks should be } \\
\text { undertaken as part of standard } \\
\text { practice and that 'if you're } \\
\text { doing your job properly, you } \\
\text { don't need these forms.' }\end{array}$ \\
\hline
\end{tabular}




\begin{tabular}{|c|c|c|c|c|c|c|}
\hline $\begin{array}{l}\text { Harrington, A., Bradley, } \\
\text { S., Jeffers, L., Linedale, E., } \\
\text { Kelman, S., \& Killington, } \\
\text { G. (2013). The } \\
\text { implementation of } \\
\text { intentional rounding using } \\
\text { participatory action } \\
\text { research. International } \\
\text { Journal of Nursing } \\
\text { Practice, 19, 523-529. } \\
\text { https://doi.org/10.1111/ijn. } \\
\underline{12101}\end{array}$ & $\begin{array}{l}\text { Qualitative- } \\
\text { Participatory } \\
\text { Action } \\
\text { Research } \\
\text { Level III B }\end{array}$ & $\begin{array}{l}\text { Inclusion and } \\
\text { exclusion criteria } \\
\text { not defined in the } \\
\text { article } \\
86 \text { patients } \\
138 \text { nursing staff }\end{array}$ & $\begin{array}{l}\text { Hourly or Intentional } \\
\text { Rounding vs. } \\
\text { conventional } \\
\text { management responds } \\
\text { to needs rather than } \\
\text { anticipating or } \\
\text { offering before } \\
\text { needed. } \\
\text { Patient Satisfaction } \\
\text { survey (not defined) } \\
\text { Staff satisfaction } \\
\text { survey (not defined) }\end{array}$ & $\begin{array}{l}\text { Participatory } \\
\text { Action } \\
\text { Research } \\
\text { (PAR) } \\
\text { The stages of } \\
\text { revision and } \\
\text { assessment } \\
\text { incorporated } \\
\text { by PAR } \\
\text { includes four } \\
\text { cycles: } \\
\text { assessment } \\
\text { (planning), } \\
\text { implementat } \\
\text { ion (action), } \\
\text { evaluation }\end{array}$ & $\begin{array}{l}\text { - Increase patient } \\
\text { care and satisfaction } \\
\text { - Improve staff } \\
\text { productivity and } \\
\text { satisfaction with } \\
\text { care delivery. } \\
\text { Patient Satisfaction } \\
\text { survey (not defined) } \\
\text { Staff satisfaction } \\
\text { survey (not defined) }\end{array}$ & $\begin{array}{l}\text { The study's outcomes revealed } \\
\text { a drop in call bell use, no } \\
\text { observable threats to patient } \\
\text { safety, nursing staff, and } \\
\text { patient satisfaction with care } \\
\text { provision. } \\
\text { Future studies should consider } \\
\text { staff skill mix issues, } \\
\text { including the needs of newly } \\
\text { graduated nursing staff as well } \\
\text { as the cognitive status of } \\
\text { patients when implementing } \\
\text { intentional rounding on acute } \\
\text { care wards }\end{array}$ \\
\hline
\end{tabular}

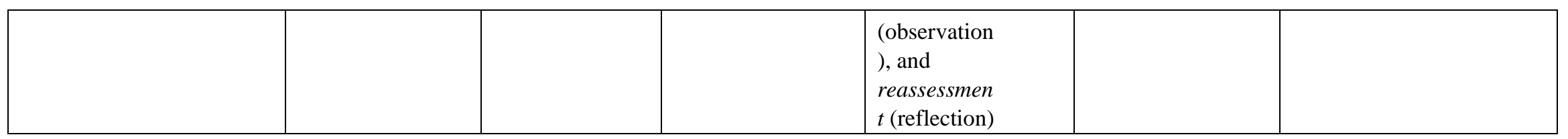




\begin{tabular}{|c|c|c|c|c|c|c|}
\hline $\begin{array}{l}\text { Kirk, K., \& Kane, R. } \\
\text { (2016). A qualitative } \\
\text { exploration of intentional } \\
\text { nursing round models in } \\
\text { the emergency department } \\
\text { setting: Investigating the } \\
\text { barriers to their use and } \\
\text { success. Journal of } \\
\text { Clinical Nursing, 25(9-10), } \\
\text { 1262-1272. } \\
\text { https://doi.org/10.1111/joc } \\
\text { n.13150 }\end{array}$ & $\begin{array}{l}\text { Qualitative } \\
\text { Level III A/B }\end{array}$ & $\begin{array}{l}\text { The sample of } \\
\text { emergency } \\
\text { department staff } \\
\text { nurses was } \\
\text { selected using a } \\
\text { nonrandom, } \\
\text { purposive } \\
\text { sampling } \\
\text { approach } \\
\text { qualified staff } \\
\text { nurses working } \\
\text { within the same } \\
\text { emergency } \\
\text { department, } \\
\text { variety of levels, } \\
\text { and work } \\
\text { experience for a } \\
\text { range of answers }\end{array}$ & $\begin{array}{l}\text { Questions asked } \\
\text { during the } \\
\text { interview "Could } \\
\text { you please share } \\
\text { with me your } \\
\text { general } \\
\text { experiences, } \\
\text { thoughts, and } \\
\text { feelings on the } \\
\text { concept of hourly } \\
\text { rounding in the } \\
\text { Emergency } \\
\text { Department, and if } \\
\text { applicable, } \\
\text { elsewhere?" } \\
\text { "How well do you } \\
\text { feel this model of } \\
\text { nursing works in } \\
\text { the } \\
\text { Emergency } \\
\text { Department } \\
\text { setting? } \\
\text { Please elaborate" } \\
\text { "Do you feel there } \\
\text { are any limitations } \\
\text { to using such a } \\
\text { are any benefits to } \\
\text { using such a model } \\
\text { in } \\
\text { the } \\
\text { Emergency } \\
\text { Department } \\
\text { setting? } \\
\text { Please elaborate" } \\
\text { anou feel there }\end{array}$ & $\begin{array}{l}\text { "Framework } \\
\text { " method of } \\
\text { qualitative data } \\
\text { analysis by Spencer } \\
\text { et al. (2014). This } \\
\text { method, which is } \\
\text { well established as } \\
\text { a tool for } \\
\text { qualitative } \\
\text { researchers }\end{array}$ & $\begin{array}{l}\text { What are the } \\
\text { barriers and } \\
\text { facilitators, as } \\
\text { perceived by } \\
\text { qualified nurses, to } \\
\text { the effective } \\
\text { implementation of } \\
\text { hourly intentional } \\
\text { nurse rounding in } \\
\text { the emergency } \\
\text { department } \\
\text { setting? }\end{array}$ & $\begin{array}{l}\text { Staff felt the } \\
\text { introduction of } \\
\text { intentional rounding } \\
\text { techniques could lead } \\
\text { to improvements in } \\
\text { patient safety and } \\
\text { overall care experience, } \\
\text { they also identified a } \\
\text { range of difficulties and } \\
\text { adaptations needed to } \\
\text { ensure its success } \\
\text { within this acute care } \\
\text { environment } \\
\text { Benefits=more open } \\
\text { communication between } \\
\text { staff and patients and } \\
\text { potentially more timely } \\
\text { response to patient needs } \\
\text { positively impacts safety } \\
\text { and satisfaction levels. } \\
\text { Barriers =lack staff } \\
\text { engagement and the } \\
\text { environmental factors and } \\
\text { pressures within the ED } \\
\text { setting }\end{array}$ \\
\hline
\end{tabular}




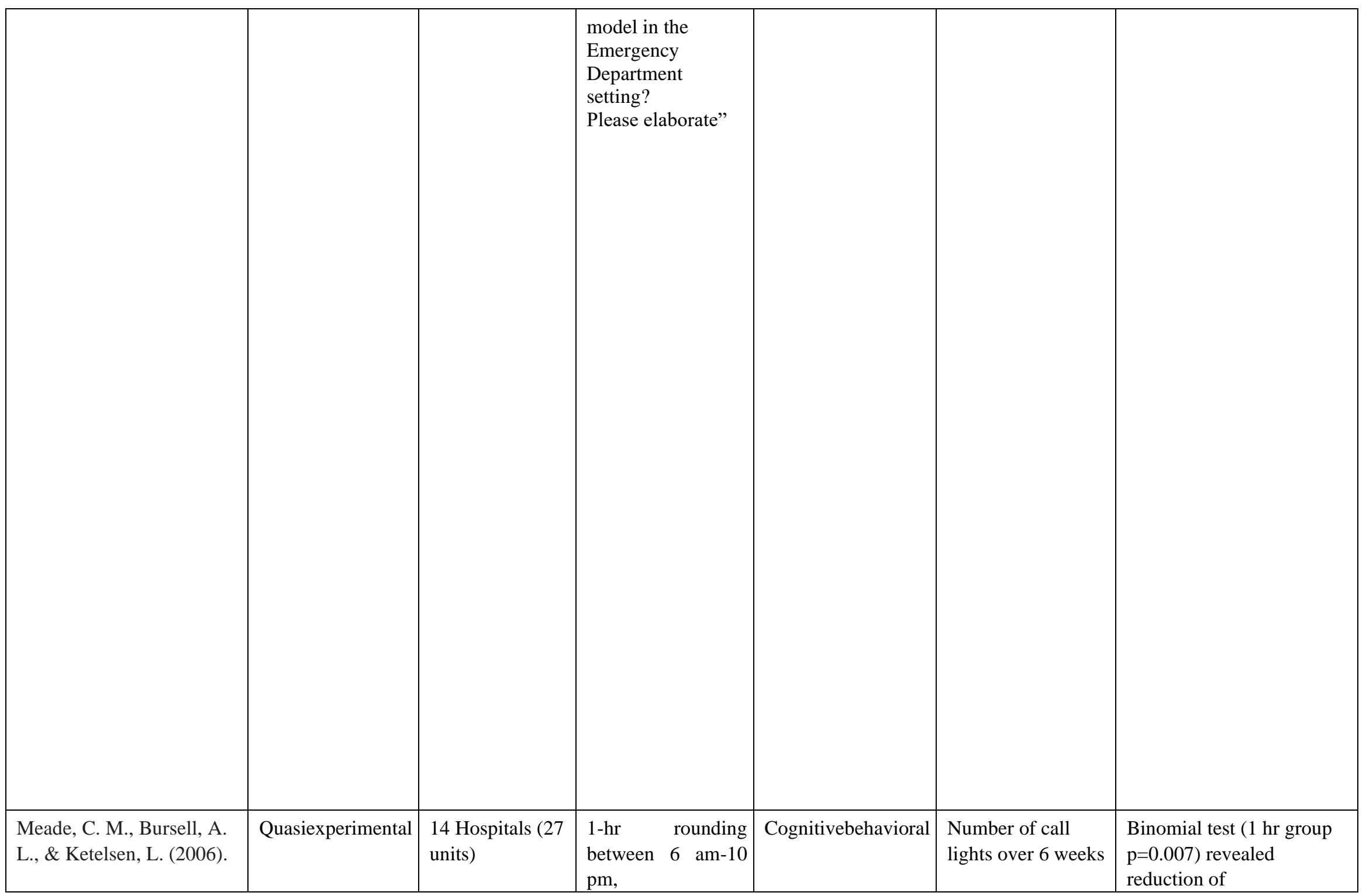




\begin{tabular}{|c|c|c|c|c|c|c|}
\hline $\begin{array}{l}\text { Effects of nursing rounds: } \\
\text { On patients' call light use, } \\
\text { satisfaction, and safety. } \\
\text { American Journal of } \\
\text { Nursing, 106(9), 58-70. } \\
\text { https://doi.org/10.1097/000 } \\
\underline{00446-200609000-00029}\end{array}$ & Level IIA & $\begin{array}{l}15 \text { Experimental } \\
\text { groups, } \\
\text { nonrandom } \\
\text { assignment of } \\
\text { either } 1 \mathrm{hr} \\
\text { rounding, } 2 \mathrm{hr} \\
\text { rounding, or } \\
\text { control; balance } \\
\text { ensured between } \\
\text { all hospitals by the } \\
\text { primary } \\
\text { investigator }\end{array}$ & $\begin{array}{l}\text { 2-hr rounding } \\
24 \mathrm{hrs} / \text { day, control } \\
\text { group collected data } \\
\text { on calls lights } \\
\text { frequency and type } \\
\text { but no prescribed } \\
\text { rounding. } \\
\text { Intervention groups } \\
\text { had intentional actions } \\
\text { based on best practice }\end{array}$ & $\begin{array}{l}\text { and learning } \\
\text { literature and } \\
\text { theory; } \\
\text { behavioral } \\
\text { shaping }\end{array}$ & $\begin{array}{l}\text { "variation } \\
\text { frequency of call } \\
\text { light use by major } \\
\text { reason category } \\
\text { overtime"; type of } \\
\text { call as predefined in } \\
\text { study } \\
\text { Patient Satisfaction } \\
\text { (different hospitals } \\
\text { used different } \\
\text { scales: NRC, Press- } \\
\text { Ganey, Professional } \\
\text { Research Group) } \\
\text { questioned overall } \\
\text { nursing quality, } \\
\text { which provided } \\
\text { consistency despite } \\
\text { different scales. } \\
\text { Mean patient } \\
\text { satisfaction was on a } \\
\text { scale of zero to } 100 \\
\text { (Likert type scales } \\
\text { from 1-5 were } \\
\text { converted to a } \\
\text { 100point scale. }\end{array}$ & $\begin{array}{l}\text { call lights for } 1 \mathrm{hr} \text { group except } \\
\text { in weeks } 3,4,5,6 \text { for two } \\
\text { categories room amenities and } \\
\text { no/reason misc ( } \mathrm{p}=0.06 \text { ) } \\
\text { Patient satisfaction }=1 \mathrm{hr} \text { group } \\
\text { went from a } 79.9 \text { score to } 91.9 \\
(\mathrm{t}=736.58, \mathrm{p}=0.0001) ; 2 \mathrm{hr} \\
\text { group went from } 70.4 \text { to } 82.1 \\
(\mathrm{t}=657.11, \mathrm{p}=0.001) \\
\text { Fall rates only had a significant } \\
\text { drop for the } 1 \mathrm{hr} \text { group }\end{array}$ \\
\hline
\end{tabular}




\begin{tabular}{|c|c|c|c|c|c|c|}
\hline $\begin{array}{l}\text { Ogbolu, Y., Scrandis, D. } \\
\text { A., Fitzpatrick, G., \& } \\
\text { Newhouse, R. (2016). } \\
\text { Leading organizational } \\
\text { cultural competency. } \\
\text { JONA: The Journal of } \\
\text { Nursing Administration, } \\
\text { 46(12), 627-629. } \\
\text { https://doi.org/10.1097/nna } \\
.0000000000000417 \\
\end{array}$ & $\begin{array}{l}\text { Qualitative } \\
\text { Level III A/B }\end{array}$ & $\begin{array}{l}\text { The study sample } \\
\text { included } \\
8 \text { CNEs from the } \\
\text { hospital } \\
\text { organizations of } \\
\text { various sizes, } \\
\text { locations, } \\
\text { teaching and } \\
\text { ownership } \\
\text { status. }\end{array}$ & $\begin{array}{l}\text { Organizational } \\
\text { Selfassessment } \\
\text { Qualitative Interview } \\
\text { Guide to examine } \\
\text { self-reported system } \\
\text { antecedents and } \\
\text { readiness factors } \\
\text { associated with } \\
\text { organizational } \\
\text { adoption of the } \\
\text { National Standards for } \\
\text { CLAS (culturally }\end{array}$ & $\begin{array}{l}\text { Not clearly } \\
\text { defined in } \\
\text { the article } \\
\text { The } \\
\text { Transcultura } \\
1 \text { Nursing } \\
\text { Theory or C } \\
\text { ulture Care } \\
\text { Theory by } \\
\text { Madeleine } \\
\text { Leininger w }\end{array}$ & $\begin{array}{l}\text { Two researchers } \\
\text { read each transcript } \\
\text { in their entirety, } \\
\text { identified } \\
\text { key codes compared } \\
\text { the codes with all } \\
\text { the other interviews } \\
\text { for similarities and } \\
\text { collapsed codes into } \\
\text { preliminary themes. } \\
\text { The } 2 \text { researchers } \\
\text { met to compare }\end{array}$ & $\begin{array}{l}\text { Need to embed cultural } \\
\text { competency with high-quality } \\
\text { care will continue to increase } \\
\text { and become an even greater } \\
\text { priority for nurse leaders. } \\
\text { One of the most important } \\
\text { recommendations noted by } \\
\text { nurse leaders focused on } \\
\text { improving the patient } \\
\text { experience by rounding to } \\
\text { identify issues, suggesting a }\end{array}$ \\
\hline & & & $\begin{array}{l}\text { and linguistically } \\
\text { appropriate services) }\end{array}$ & $\begin{array}{l}\text { ould fit this } \\
\text { research }\end{array}$ & $\begin{array}{l}\text { codes and reached a } \\
\text { consensus on the } \\
\text { final themes. }\end{array}$ & $\begin{array}{l}\text { need for additional } \\
\text { interventions supporting } \\
\text { culturally sensitive care. } \\
\text { Rounds may include other } \\
\text { nurse leaders as champions in } \\
\text { addition to the nurse manager } \\
\text { to interact with patients and } \\
\text { inquire about their experiences } \\
\text { during all phases of care } \\
\text { Purposeful nurse leader } \\
\text { rounding requires empathy and } \\
\text { deep listening for } \\
\text { understanding } \\
\text { Rounding is an effective } \\
\text { strategy for building } \\
\text { relationships and trust, all of } \\
\text { which are necessary for the } \\
\text { delivery of CLAS. }\end{array}$ \\
\hline
\end{tabular}




\begin{tabular}{|c|c|c|c|c|c|c|}
\hline $\begin{array}{l}\text { Rondinelli, J., Ecker, M., } \\
\text { Crawford, C., Seelinger, C., } \\
\text { \& Omery, A. (2012). } \\
\text { Hourly rounding } \\
\text { implementation: A } \\
\text { multisite description of } \\
\text { structures, processes, and } \\
\text { outcomes. JONA: The } \\
\text { Journal of Nursing } \\
\text { Administration, 42(6), 326- } \\
\text { 332. } \\
\text { https://doi.org/10.1097/nna } \\
.0 \text { 013e31824ccd43 }\end{array}$ & $\begin{array}{l}\text { Social Action } \\
\text { Research } \\
\text { Qualitative } \\
\text { Level III- B }\end{array}$ & $\begin{array}{l}\text { Fourteen } \\
\text { interviewees } \\
\text { participated, } \\
\text { representing Eight } \\
\text { hospitals in the } \\
\text { Southern } \\
\text { California Kaiser } \\
\text { Permanente the } \\
\text { integrated } \\
\text { healthcare } \\
\text { organization, and } \\
3 \text { hospitals from } \\
\text { different } \\
\text { healthcare } \\
\text { organizations in } \\
\text { the area. } \\
\text { Interviews } \\
\text { occurred from } \\
\text { December } 2007 \text { to } \\
\text { August 2008. The }\end{array}$ & $\begin{array}{l}\text { All codes were } \\
\text { synthesized into } \\
\text { themes, with each } \\
\text { theme labeled and } \\
\text { defined. Defined } \\
\text { themes, along with } \\
\text { sample exemplars, } \\
\text { were sent to a } \\
\text { voluntary group } \\
\text { consisting of project } \\
\text { leads, advanced } \\
\text { practice nurses, } \\
\text { and/or nurse } \\
\text { scientists. This group } \\
\text { independently } \\
\text { validated whether the } \\
\text { exemplars fit the } \\
\text { assigned definition } \\
\text { and if the definition } \\
\text { fit the assigned theme }\end{array}$ & $\begin{array}{l}\text { The } \\
\text { Donabedian } \\
\text { model of the } \\
\text { structure, } \\
\text { process, and } \\
\text { outcome } \\
\text { provides the } \\
\text { framework } \\
\text { for this study }\end{array}$ & $\begin{array}{l}\text { For each interview, } \\
\text { answers to } \\
\text { openended questions } \\
\text { were transcribed } \\
\text { verbatim. All } \\
\text { interview responses } \\
\text { were searched for } \\
\text { meaningful } \\
\text { segments, referred to } \\
\text { as exemplars. } \\
\text { Manual indexing } 19 \\
\text { was used to record } \\
\text { exemplars, which } \\
\text { were organized into } \\
\text { code categories. } \\
\text { Code categories } \\
\text { were evaluated by } 2 \\
\text { independent }\end{array}$ & $\begin{array}{l}\text { The authors recommend the } \\
\text { abandonment of routinization } \\
\text { and the adoption of flexibility } \\
\text { to sustain the successful } \\
\text { implementation of hourly } \\
\text { rounding. } \\
\text { Unintended outcomes } \\
\text { emerged during content } \\
\text { analysis: patient perception of } \\
\text { being well cared for, efficient } \\
\text { nursing practice, expert } \\
\text { nursing practice, and } \\
\text { realization of both unit and } \\
\text { individual practice culture. }\end{array}$ \\
\hline
\end{tabular}




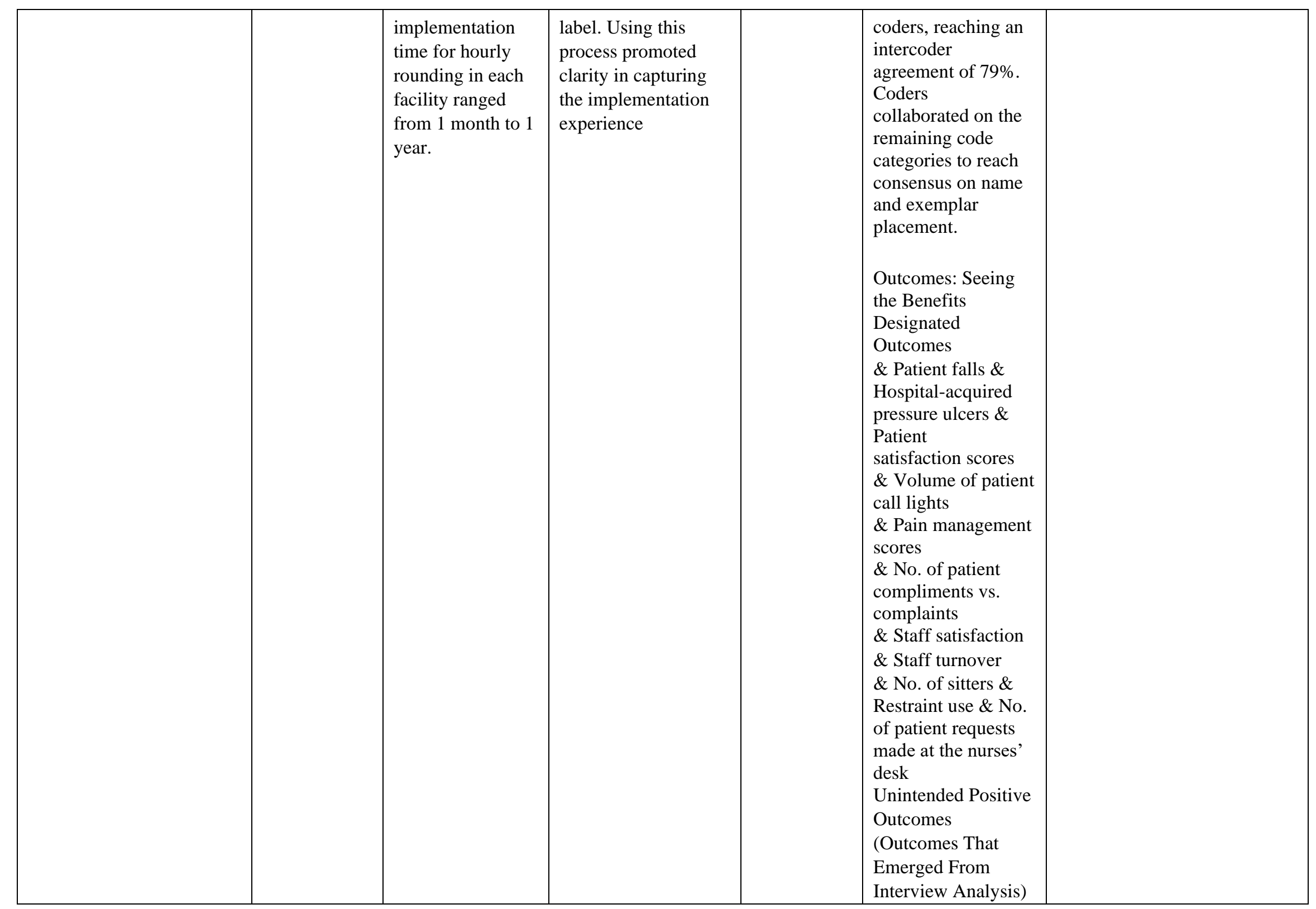




\begin{tabular}{|l|l|l|l|l|}
\hline & & & & $\begin{array}{l}\text { \& Patient perception } \\
\text { of being well cared } \\
\text { for } \\
\text { \& Efficient nursing } \\
\text { practice } \\
\text { \& Expert nursing } \\
\text { practice } \\
\text { \& Realization of } \\
\text { both unit and } \\
\text { individual practice } \\
\text { culture }\end{array}$ \\
\hline
\end{tabular}




\begin{tabular}{|c|c|c|c|c|c|c|}
\hline $\begin{array}{l}\text { Shin, N., \& Park, J. (2018). } \\
\text { The effect of intentional } \\
\text { nursing rounds based on the } \\
\text { care model on patients' } \\
\text { perceived nursing quality } \\
\text { and their satisfaction with } \\
\text { nursing services. Asian } \\
\text { Nursing Research, 12(3), } \\
\text { 203-208. } \\
\text { https://doi.org/10.1016/j.an } \\
\text { r.2018.08.003 }\end{array}$ & $\begin{array}{l}\text { Quasiexperimental } \\
\text { Level II-B }\end{array}$ & $\begin{array}{l}70 \text { patients } \\
\text { (experimental } \\
\text { group) and } 75 \\
\text { patients (control } \\
\text { group). The } \\
\text { Control group and } \\
\text { experimental } \\
\text { group were } \\
\text { assigned } \\
\text { according to the } \\
\text { admission order, } \\
\text { and experimental } \\
\text { groups were } \\
\text { allocated after the } \\
\text { treatment of the } \\
\text { control group with } \\
\text { the time } \\
\text { difference. }\end{array}$ & $\begin{array}{l}\text { (1) hypothesis 1-The } \\
\text { experimental group } \\
\text { under intentional } \\
\text { nursing rounds will } \\
\text { reveal a higher level } \\
\text { of perceived nursing } \\
\text { quality than the } \\
\text { control group } \\
\text { without rounding } \\
\text { service; This factor } \\
\text { was measured in this } \\
\text { study by adopting a } \\
\text { tool called PQNCS. } \\
\text { This tool consists of } \\
\text { a set of } 10 \text { items } \\
\text { measured on a } \\
\text { fivepoint scale, and a } \\
\text { higher score means a } \\
\text { higher level of } \\
\text { perceived nursing } \\
\text { quality. The } \\
\text { reliability of the } \\
\text { scale, Cronbach's a, } \\
\text { was obtained at } .81 \\
\text { in their research and } \\
0.94 \text { in this research. } \\
\text { (2) hypothesis- The } \\
\text { experimental group }\end{array}$ & $\begin{array}{l}\text { PPM Model } \\
\text { based on } \\
\text { Swanson's } \\
\text { Care model } \\
\text { Theoretical } \\
\text { development } \\
\text { program } \\
\text { involving } \\
\text { six basic } \\
\text { principles } \\
\text { which are } \\
\text { maintaining } \\
\text { belief, } \\
\text { knowing, } \\
\text { being with, } \\
\text { doing for, } \\
\text { enabling, and } \\
\text { patients' } \\
\text { wellness }\end{array}$ & $\begin{array}{l}\text { PQNCS (nursing } \\
\text { quality); PSNSCQQ } \\
\text { (satisfaction with } \\
\text { nursing service); }\end{array}$ & $\begin{array}{l}\text { Intentional nursing rounds } \\
\text { based on the care model } \\
\text { effectively improved the } \\
\text { perception of quality nursing } \\
\text { care and patients' satisfaction } \\
\text { with nursing care. } \\
\text { Structured patient-oriented } \\
\text { intentional nursing rounds } \\
\text { based on the care model are } \\
\text { expected to expand to a } \\
\text { variety of clinical settings } \\
\text { further. }\end{array}$ \\
\hline & & & $\begin{array}{l}\text { under intentional } \\
\text { nursing, rounds will } \\
\text { reveal a higher level } \\
\text { of satisfaction with } \\
\text { nursing services } \\
\text { than the control } \\
\text { group without } \\
\text { rounding service. }\end{array}$ & & & \\
\hline
\end{tabular}


Legend: Perception of Quality Nursing Care Scale (PQNCS) and the Patients' Satisfaction with Nursing Care Quality Questionnaire (PSNCQQ). 


\section{Appendix B}

\section{Summary of Systematic Reviews (SR)}

\begin{tabular}{|c|c|c|c|c|c|c|c|}
\hline Citation & $\begin{array}{l}\text { Quality } \\
\text { Grade }\end{array}$ & Question & Search Strategy & $\begin{array}{l}\text { Inclusion/ } \\
\text { Exclusion Criteria }\end{array}$ & $\begin{array}{l}\text { Data Extraction } \\
\text { and Analysis }\end{array}$ & Key Findings & $\begin{array}{l}\text { Usefulness/Recommendati } \\
\text { on/ } \\
\text { Implications }\end{array}$ \\
\hline $\begin{array}{l}\text { Rea, K. E., } \\
\text { Rao, P., Hill, } \\
\text { E., } \\
\text { Saylor, K. } \\
\text { M., \& } \\
\text { Cousino, M. } \\
\text { K. (2018). } \\
\text { Families' } \\
\text { experiences } \\
\text { with pediatric } \\
\text { familycentered } \\
\text { rounds: A } \\
\text { systematic } \\
\text { review. } \\
\text { Pediatrics, } \\
\text { 141(3), } \\
\text { e20171883. } \\
\text { https://doi.or }\end{array}$ & $\begin{array}{l}\text { Level } \\
\text { II-A }\end{array}$ & $\begin{array}{l}\text { (1) What are } \\
\text { families' overall } \\
\text { experiences with } \\
\text { the current model } \\
\text { of FCR? (2) How } \\
\text { do families } \\
\text { perceive FCR? } \\
\text { (3) What benefits } \\
\text { or disadvantages } \\
\text { do families see in } \\
\text { FCR? }\end{array}$ & \begin{tabular}{|l} 
Following \\
Cochrane \\
guidelines \\
The \\
informationist \\
revised the \\
PubMed search \\
strategy and \\
translated it \\
across the \\
following \\
databases: \\
Cumulative \\
Index to Nursing \\
and \\
Allied Health \\
Literature \\
(CINAHL; \\
EBSCO), PsycInfo \\
(EBSCO), Scopus \\
(Elsevier), and \\
Embase (Elsevier).
\end{tabular} & \begin{tabular}{||l} 
Inclusion criteria were \\
as follows: \\
being published in a \\
peer-reviewed \\
journal between January \\
2007 and \\
February 2017 is \\
written in the English \\
language, having a \\
study population \\
including pediatric \\
patients (0-21 years), \\
and \\
having measurement \\
of a specific outcome \\
of a family's \\
experience with \\
FCR (e.g., \\
psychosocial outcomes, \\
understanding of the \\
plan and/or medical \\
information, \\
relationship with the \\
medical team,
\end{tabular} & \begin{tabular}{||l} 
One author \\
(K.E.R.) reviewed \\
titles and abstracts \\
of all results, and 2 \\
authors (K.E.R. and \\
P.R.) independently \\
examined the \\
remaining articles' \\
full text for study \\
inclusion and data \\
extraction. Data \\
extracted included \\
sample size, \\
participating \\
medical unit, \\
measures of family \\
experience, and \\
overall results. \\
Analysis of bias \\
revealed that most \\
researchers used an \\
investigatordesigned
\end{tabular} & \begin{tabular}{|l}
18 studies in the last \\
5 \\
Overall, parents \\
who attend FCR had \\
high satisfaction but \\
limited data to \\
compare to standard \\
rounding \\
FCR did not \\
significantly reduce \\
parents stress, but \\
one study showed a \\
reduction in anxiety \\
Disadvantages \\
include non-English \\
population \\
satisfaction and \\
poor communication \\
when a translator \\
was used. Families \\
felt disempowered \\
to speak up
\end{tabular} & $\begin{array}{l}\text { Using medical jargon } \\
\text { impacts PFX with FCR and } \\
\text { should be avoided } \\
\text { Steps should be taken to } \\
\text { ensure families understand } \\
\text { FCR, such as a brochure, } \\
\text { magnet on the door, and } \\
\text { explanation } \\
\text { Limited research with } \\
\text { adolescents' experiences } \\
\text { Implementing tools specific } \\
\text { to children such as My } \\
\text { CHATT tool are needed } \\
\text { Future research to look at } \\
\text { the efficacy of } \\
\text { implementing patient- } \\
\text { centered communication } \\
\text { and rounding preferences } \\
\text { tools } \\
\text { Non-English families have } \\
\text { decreased positive }\end{array}$ \\
\hline
\end{tabular}




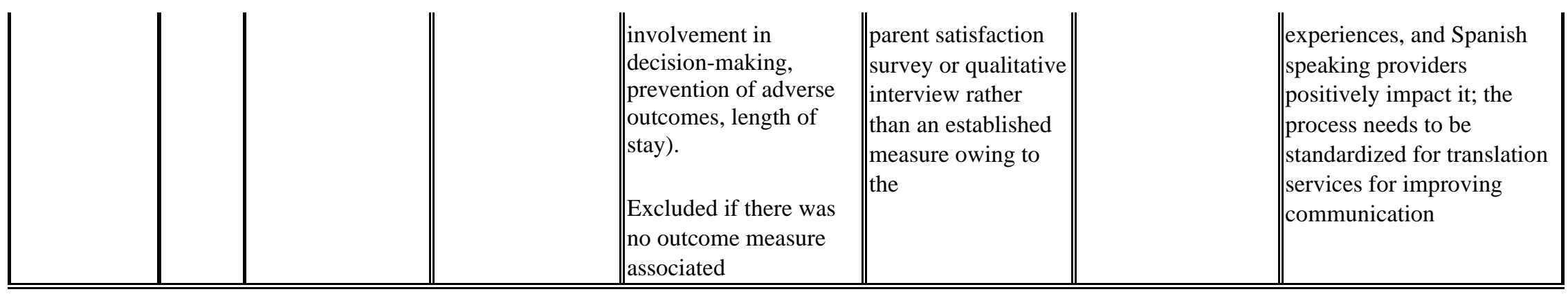

\begin{tabular}{|l|l|l||l||l||l||l|}
\hline \hline Citation & $\begin{array}{l}\text { Quality } \\
\text { Grade }\end{array}$ & Question & Search Strategy & $\begin{array}{l}\text { Inclusion/ } \\
\text { Exclusion Criteria }\end{array}$ & $\begin{array}{l}\text { Data Extraction } \\
\text { and Analysis }\end{array}$ & Key Findings \\
Usefulness/Recommendati \\
on/ \\
Implications
\end{tabular}




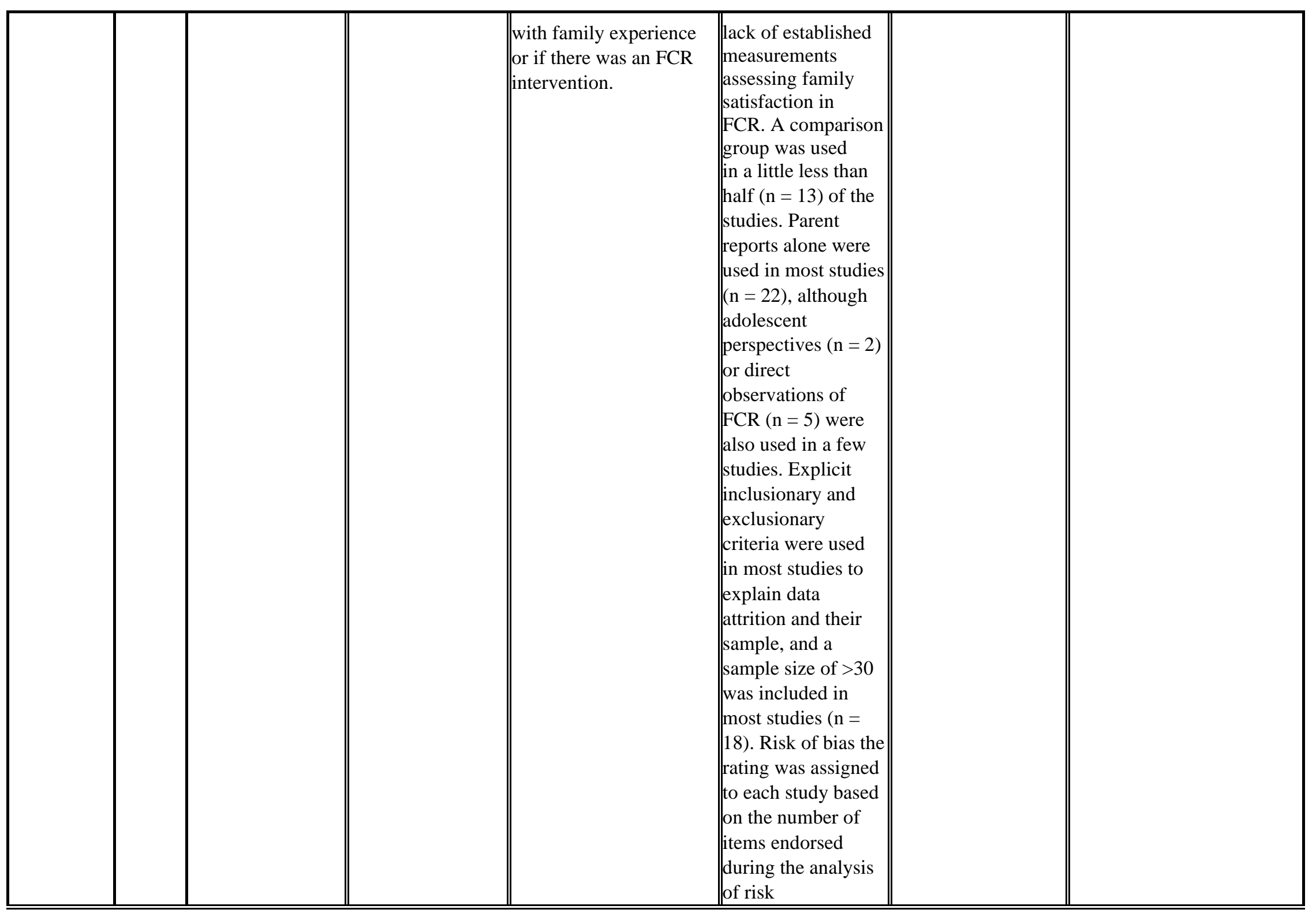




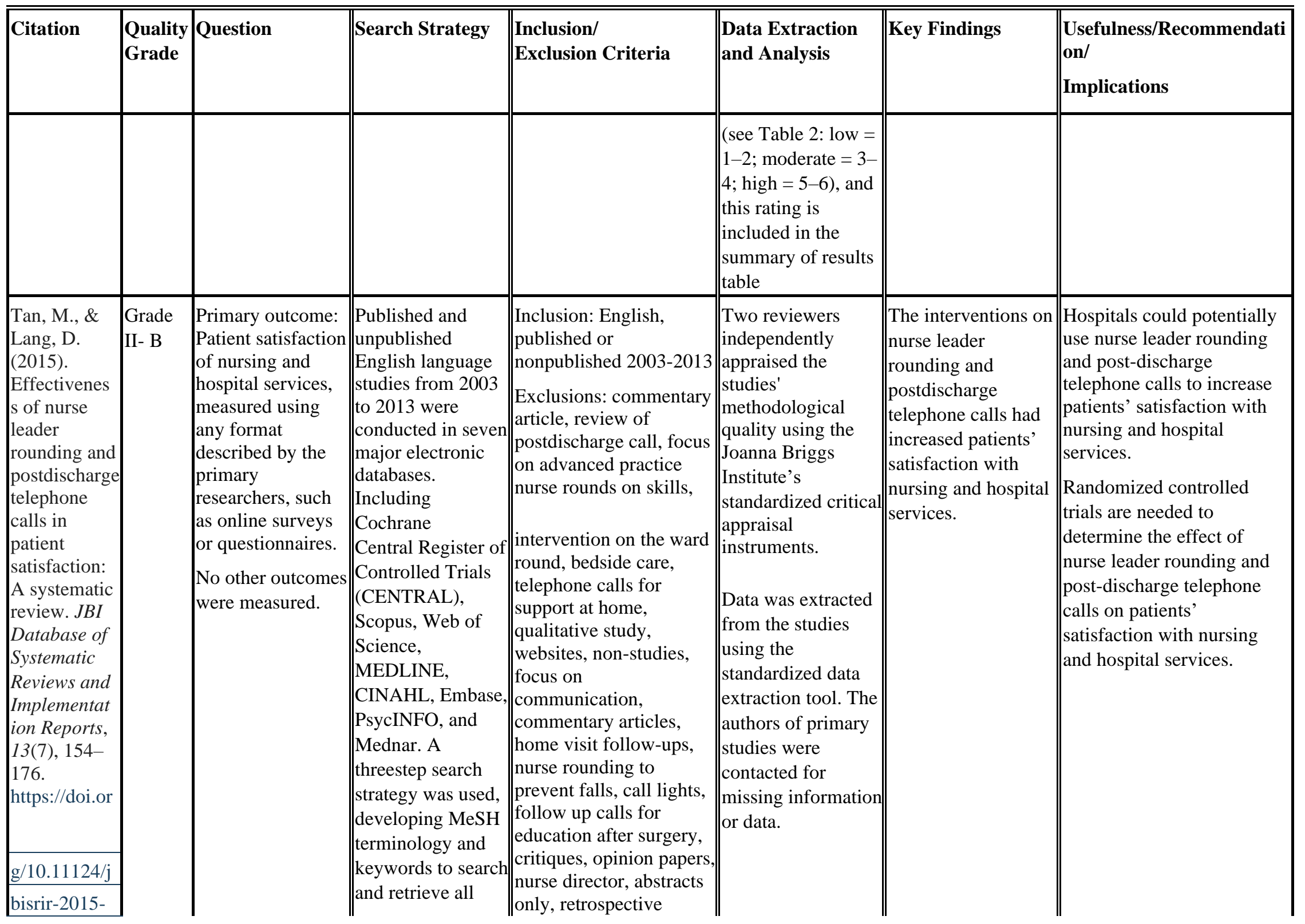




\begin{tabular}{|l|l||l||l||||||}
\hline 2013 & $\begin{array}{l}\text { relevant literature } \\
\text { for the review }\end{array}$ & $\begin{array}{l}\text { reports, post-discharge } \\
\text { call, } \\
\text { continuing education } \\
\text { article, }\end{array}$ & \\
\hline \hline
\end{tabular}




\section{Appendix C}

\section{SWOT Analysis}

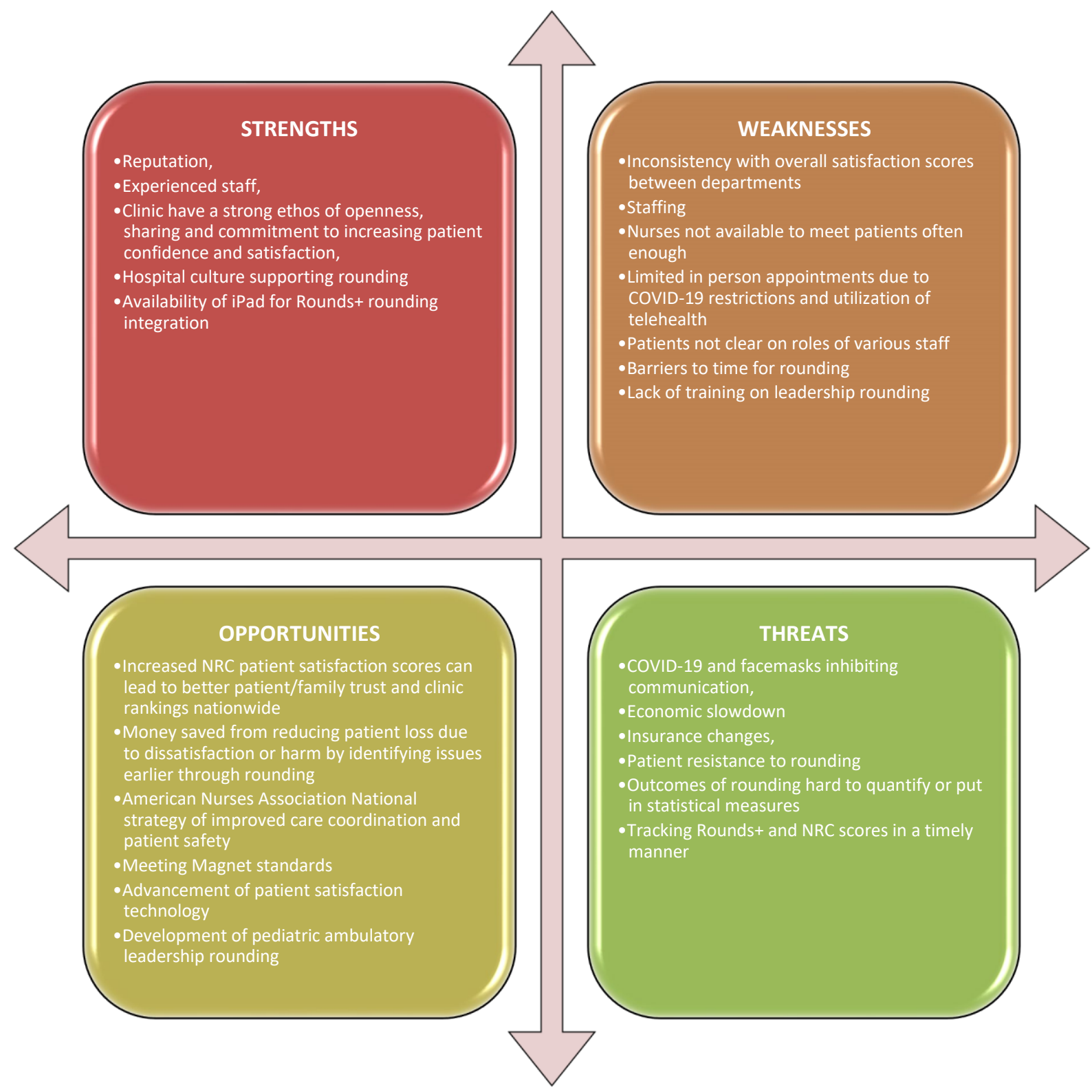




\section{Appendix D}

\section{Ambulatory Leadership Rounding Survey}

1. Rounding taking place: Waiting room or exam room

\section{GENERAL:}

1. Good morning/afternoon, my name is I am a (role) here at Children's Hospital. Thank you for choosing us to care for your child. I am visiting patients to ensure that we are providing great care.

a. Are we meeting this commitment?

b. Ask at least one of these:

i. Do you have any concerns right now that I can help address?

ii. We want to make sure all your needs are met. Can you tell me what matters most to you right now?

iii. As part of our caring community, we want to be sure to respect your family's needs. Are there any cultural practices or activities you would like us to observe when we come to Children's (or come to ..state clinic name)?

c. I see that is your RN/Provider today. You are in excellent hands.

2. Were there any delays with being seen today? a. If yes, what reason was given for the delay?

a. Suggested wording for a long wait if in the waiting room:

i. We want to give each child the care they need. Because of this, we sometimes run behind schedule. We will make sure your child gets the time they need as well.

\section{COMMUNICATION:}

1. Has the communication between the care team been consistent and clear? a. If no, add comments:

\section{RECOGNITION:}

1. Any recommendations or kudos

\section{Final Comment-}

We want to be sure to provide you and your child with excellent care. At any time, if you do not feel you are receiving excellent care, please contact me at (leave a business card). 


\section{Appendix E}

Project Schedule

\begin{tabular}{|c|c|c|c|c|c|c|c|c|c|c|c|c|c|c|c|c|c|c|c|c|c|c|c|c|}
\hline & \multicolumn{8}{|c|}{ NUR7801 } & \multicolumn{8}{|c|}{ NUR7802 } & \multicolumn{8}{|c|}{ NUR7803 } \\
\hline 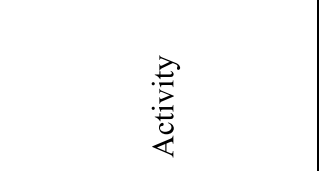 & $\begin{array}{l}\vec{y} \\
\frac{y}{0} \\
3\end{array}$ & $\begin{array}{l}m \\
y \\
y \\
z\end{array}$ & $\begin{array}{l}n \\
y \\
0 \\
z\end{array}$ & $\frac{1}{y}$ & $\begin{array}{l}a \\
\frac{y}{0} \\
3\end{array}$ & $\begin{array}{l}= \\
y \\
y \\
z\end{array}$ & $\begin{array}{l}\frac{m}{8} \\
\frac{\pi}{8} \\
\frac{8}{3}\end{array}$ & $\begin{array}{l}n \\
\frac{\pi}{8} \\
8 \\
3\end{array}$ & $\begin{array}{l}\vec{y} \\
\frac{x}{3} \\
3\end{array}$ & $\frac{m}{y}$ & 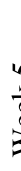 & $\frac{r}{y}$ & $\begin{array}{l}a \\
\frac{u}{d} \\
3\end{array}$ & $\begin{array}{l}= \\
y \\
\overline{8} \\
3\end{array}$ & $\begin{array}{l}\frac{m}{y} \\
\frac{\pi}{8} \\
\frac{0}{3}\end{array}$ & $\begin{array}{l}\frac{n}{2} \\
\frac{\pi}{0} \\
3\end{array}$ & $\begin{array}{l}\sqrt{y} \\
\frac{0}{3}\end{array}$ & $\begin{array}{l}m \\
\frac{y}{j} \\
z \\
z\end{array}$ & $\begin{array}{l}n \\
\frac{y}{0} \\
z\end{array}$ & $\frac{\bar{y}}{y}$ & $\begin{array}{l}a \\
\frac{y}{3} \\
3\end{array}$ & $\begin{array}{l}= \\
\bar{\Xi} \\
3\end{array}$ & $\begin{array}{l}\frac{m}{y} \\
\frac{\pi}{8} \\
3\end{array}$ & $\begin{array}{l}\frac{n}{y} \\
\frac{y}{d} \\
3\end{array}$ \\
\hline Meet with preceptor & $\mathrm{X}$ & $\mathrm{X}$ & $\mathrm{X}$ & $\mathrm{X}$ & $\mathrm{X}$ & $\mathrm{X}$ & $\mathrm{X}$ & $\mathrm{X}$ & $\mathrm{X}$ & $\mathrm{X}$ & & $\mathrm{X}$ & $\mathrm{X}$ & $\mathrm{X}$ & $\mathrm{X}$ & $\mathrm{X}$ & $X$ & $\mathrm{X}$ & $\mathrm{X}$ & $\mathrm{X}$ & $\mathrm{X}$ & $\mathrm{X}$ & $\mathrm{X}$ & $\mathrm{X}$ \\
\hline Prepare project proposal & $\mathrm{X}$ & $X$ & $\mathrm{X}$ & $\mathrm{X}$ & $\mathrm{X}$ & $\mathrm{X}$ & $\mathrm{X}$ & & & & & & & & & & & & & & & & & \\
\hline $\begin{array}{l}\text { Create urgency by } \\
\text { discussing with } \\
\text { directors and } \\
\text { managers the need for } \\
\text { increased patient } \\
\text { satisfaction and } \\
\text { rounding }\end{array}$ & & & $\mathrm{X}$ & & & & & & & & & & & & & & & & & & & & & \\
\hline Literature Review & & & $\mathrm{X}$ & $\mathrm{X}$ & & & & & & & & & & & & & & & & & & & & \\
\hline SWOT Analysis & & & & & $\mathrm{X}$ & & & & & & & & & & & & & & & & & & & \\
\hline $\begin{array}{l}\text { Stakeholder } \\
\text { Determination }\end{array}$ & & & & & $\mathrm{X}$ & & & & & & & & & & & & & & & & & & & \\
\hline $\begin{array}{l}\text { Develop Leadership } \\
\text { Rounding Tool }\end{array}$ & & & & & & $\mathrm{X}$ & & & & & & & & & & & & & & & & & & \\
\hline Metrics Development & & & & & & $\mathrm{X}$ & & & & & & & & & & & & & & & & & & \\
\hline Submit Project Proposal & & & & & & & $\mathrm{X}$ & & & & & & & & & & & & & & & & & \\
\hline Faculty Approval & & & & & & & & $\mathrm{X}$ & $\mathrm{X}$ & & & & & & & & & & & & & & & \\
\hline Preceptor Approval & & & & & & & & $\mathrm{X}$ & $\mathrm{X}$ & & & & & & & & & & & & & & & \\
\hline $\begin{array}{l}\text { USA IRB/Project } \\
\text { Approval }\end{array}$ & & & & & & & & & & $\mathrm{X}$ & & & & & & & & & & & & & & \\
\hline $\begin{array}{l}\text { CHCO Project } \\
\text { Approval }\end{array}$ & & & & & & & & & & & & & & & & & & & & & & & & \\
\hline
\end{tabular}




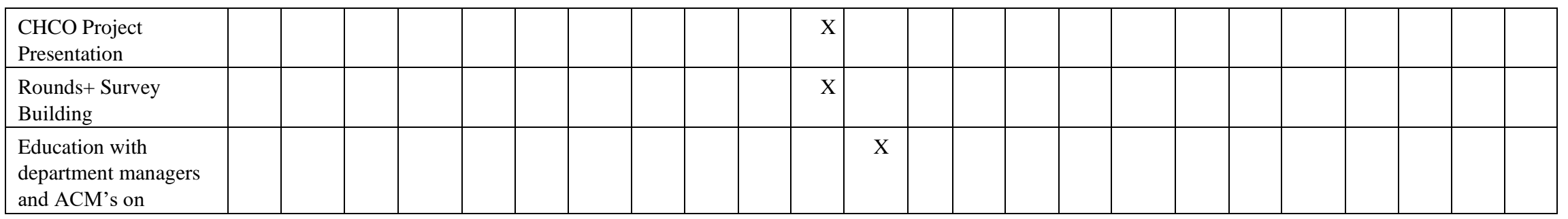

\begin{tabular}{|c|c|c|c|c|c|c|c|c|c|c|c|c|c|c|c|c|c|c|c|c|c|c|c|c|}
\hline & \multicolumn{8}{|c|}{ NUR7801 } & \multicolumn{8}{|c|}{ NUR7802 } & \multicolumn{8}{|c|}{ NUR7803 } \\
\hline 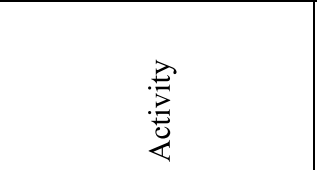 & $\frac{\sqrt{4}}{3}$ & $\begin{array}{l}m \\
\frac{n}{8} \\
3\end{array}$ & $\begin{array}{l}n \\
\frac{y}{8} \\
3\end{array}$ & $\frac{5}{3}$ & $\frac{a}{y}$ & $\begin{array}{l}= \\
y \\
\frac{y}{2} \\
3\end{array}$ & $\begin{array}{l}\frac{m}{y} \\
\frac{y}{8} \\
3\end{array}$ & $\begin{array}{l}n \\
\frac{y}{8} \\
\frac{0}{3}\end{array}$ & $\frac{\bar{y}}{3}$ & $\frac{m}{3}$ & $\begin{array}{l}n \\
\frac{y}{0} \\
3\end{array}$ & $\frac{5}{3}$ & $\begin{array}{l}a \\
\frac{y}{d} \\
3 \\
3\end{array}$ & $\begin{array}{l}\exists \\
y \\
\bar{y} \\
3\end{array}$ & $\begin{array}{l}m \\
\frac{m}{d} \\
3\end{array}$ & $\begin{array}{l}\frac{n}{4} \\
\frac{y}{8} \\
3\end{array}$ & $\frac{\bar{y}}{3}$ & $\frac{n}{\frac{n}{4}}$ & $\begin{array}{l}n \\
\frac{n}{0} \\
3 \\
3\end{array}$ & $\frac{5}{y}$ & $\frac{a}{y}$ & $\begin{array}{l}= \\
\frac{y}{8} \\
3\end{array}$ & $\begin{array}{l}m \\
\frac{m}{8} \\
\dot{y}\end{array}$ & $\begin{array}{l}n \\
\frac{1}{8} \\
\frac{1}{3}\end{array}$ \\
\hline $\begin{array}{l}\text { Rounds+ survey, } \\
\text { planning days and times } \\
\text { for rounding } \\
\text { intervention }\end{array}$ & & & & & & & & & & & & & & & & & & & & & & & & \\
\hline Collect Baseline Data & & & & & & & & & & & & $\mathrm{X}$ & & & & & & & & & & & & \\
\hline $\begin{array}{l}\text { Implementation of } \\
\text { Leadership Rounding }\end{array}$ & & & & & & & & & & & & & & & $\mathrm{X}$ & $\mathrm{X}$ & & & & & & & & \\
\hline $\begin{array}{l}\text { Incentive for meeting } \\
\text { rounding goals for the } \\
\text { first } 2 \text { weeks }\end{array}$ & & & & & & & & & & & & & & & $\mathrm{X}$ & & & & & & & & & \\
\hline $\begin{array}{l}\text { Collect first month } \\
\text { measures }\end{array}$ & & & & & & & & & & & & & & & & $\mathrm{X}$ & & & & & & & & \\
\hline Stakeholder Update & & & & & & & & & & & & & & & $\mathrm{X}$ & & & & & & & & & \\
\hline $\begin{array}{l}\text { End of intervention } \\
\text { celebration }\end{array}$ & & & & & & & & & & & & & & & & $\mathrm{X}$ & & & & & & & & \\
\hline $\begin{array}{l}\text { Collect end intervention } \\
\text { measurements }\end{array}$ & & & & & & & & & & & & & & & & & $\mathrm{X}$ & & & & & & & \\
\hline $\begin{array}{l}\text { Stakeholder Updates } \\
\text { post-intervention }\end{array}$ & & & & & & & & & & & & & & & & & & $\mathrm{X}$ & & & & & & \\
\hline
\end{tabular}




\begin{tabular}{|l|l|l|l|l|l|l|l|l|l|l|l|l|l|l|l|l|l|l|l|l|l|l|l|}
\hline $\begin{array}{l}\text { Evaluate data \& } \\
\text { outcomes }\end{array}$ & & & & & & & & & & & & & & & & & & & & & & & \\
\hline Debriefing
\end{tabular}




\section{Appendix F}

Measures and Results

\begin{tabular}{|c|c|c|c|c|}
\hline Measure & Benchmark & Goal & $\begin{array}{c}\text { Statistical } \\
\text { Test }\end{array}$ & Data Type \\
\hline $\begin{array}{l}\text { Outcome measure: } \\
\text { Overall patient satisfaction score -Percent } \\
\text { positive Score (\% of respondents } \\
\text { selecting top response) (NRC Report) }\end{array}$ & $\begin{array}{c}80 \% \text { overall } \\
\text { patient } \\
\text { satisfaction }\end{array}$ & $\geq 75 \%$ & $\mathrm{x}^{2}$ & Ordinal \\
\hline $\begin{array}{l}\text { Outcome measure: } \\
\text { Did nurses listen carefully to you? - } \\
\text { Percent positive Score (\% of respondents } \\
\text { selecting top response) (NRC Report) }\end{array}$ & $80 \%$ & $\geq 75 \%$ & $x^{2}$ & Ordinal \\
\hline $\begin{array}{l}\text { Outcome measure: } \\
\text { Did you have confidence and trust in the } \\
\text { nurses treating you? - Percent positive } \\
\text { Score (\% of respondents selecting top } \\
\text { response) (NRC Report) }\end{array}$ & $80 \%$ & $\geq 75 \%$ & $x^{2}$ & Ordinal \\
\hline $\begin{array}{l}\text { Outcome measure: } \\
\text { Percentage of rounds responses that state } \\
\text { they received great care. Denominator is } \\
\text { the total number of rounds; the numerator } \\
\text { is total \# of yes responses on the Rounds+ } \\
\text { rounding survey. }\end{array}$ & $80 \%$ & $\geq 75 \%$ & $x^{2}$ & Ordinal \\
\hline $\begin{array}{l}\text { Outcome measure: } \\
\text { Percentage of rounds responses that state } \\
\text { the communication between the care team } \\
\text { was consistent. Denominator is total } \\
\text { number of rounds, numerator is total \# of } \\
\text { yes responses on the Rounds+ rounding } \\
\text { survey. }\end{array}$ & $80 \%$ & $\geq 75 \%$ & $x^{2}$ & Ordinal \\
\hline
\end{tabular}




\begin{tabular}{|c|c|c|c|c|}
\hline $\begin{array}{l}\text { Outcome measure: } \\
\text { Rate of leader satisfaction with the } \\
\text { rounding process. Measured with Likert } \\
\text { scores of } 0 \text { not satisfied to } 5 \text { Very } \\
\text { Satisfied }\end{array}$ & Satisfied & $\geq$ Satisfied & Paired ttest & Ordinal \\
\hline $\begin{array}{l}\text { Process Measure } \\
\text { Total number of rounds completed } \\
\text { weekly per clinic and per family or } \\
\text { patient (depending on over or under } 18 \\
\text { years of age) }\end{array}$ & 20 & $\geq 20$ & & Nominal \\
\hline $\begin{array}{l}\text { Process Measure } \\
\text { Percentage of visits that had a nurse } \\
\text { present for care. Denominator is total } \\
\text { number of surveys and numerator is } \\
\text { number of RN visits. Result is multiplied } \\
\text { by } 100 \text {. }\end{array}$ & & $\geq 50 \%$ & & Nominal \\
\hline $\begin{array}{l}\text { Process Measure } \\
\text { Wait times for patient, defined as time to } \\
\text { check in until time seeing the scheduled } \\
\text { provider }\end{array}$ & & $\leq 10$ minutes & & Ordinal \\
\hline $\begin{array}{l}\text { Balance Measure } \\
\text { Average time spent on rounding weekly. } \\
\text { Total time spent Rounds+ Survey } \\
\text { rounding/ total number of nurse leader } \\
\text { participants }\end{array}$ & 1 hour & $\begin{array}{c}\leq 2 \\
\text { hours/week }\end{array}$ & & Nominal \\
\hline $\begin{array}{l}\text { Financial Measure } \\
\text { Cost of nurse leaders' time }\end{array}$ & $\begin{array}{c}\text { Salary for } \\
\text { Manager X2 } \\
\text { (4hr/month) } \\
\text { Salary for } \\
\text { ACM X2 } \\
\text { (4hr/month) } \\
\text { Total= \$3360 }\end{array}$ & & & \\
\hline $\begin{array}{l}\text { Financial Measure } \\
\text { Salary for Rounds+ representative in } \\
\text { hospital ( } 4 \text { hrs for developing questions) }\end{array}$ & Total $=\$ 200$ & & & \\
\hline
\end{tabular}




\begin{tabular}{|c|c|c|}
\hline Sustainability Measure & $\leq 3$ & Continuous \\
\hline $\begin{array}{l}\text { The total number of days per week } \\
\text { rounding was not completed due to } \\
\text { leaders' time constraints. }\end{array}$ & & Data \\
\hline
\end{tabular}

